\title{
Repurposing Drugs in Oncology (ReDO)—clarithromycin as an anti-cancer agent
}

\author{
An MT Van Nuffel ${ }^{1}$, Vidula Sukhatme ${ }^{2}$, Pan Pantziarka ${ }^{1,3}$, Lydie Meheus ${ }^{1}$, Vikas P Sukhatme ${ }^{2,4}$ and Gauthier Bouche ${ }^{1}$ \\ ${ }^{1}$ Anticancer Fund, Brussels, 1853 Strombeek-Bever, Belgium \\ ${ }^{2}$ GlobalCures, Inc, Newton, MA 02459, USA \\ ${ }^{3}$ The George Pantziarka TP53 Trust, London KT1 2JP, UK \\ ${ }^{4}$ Beth Israel Deaconess Medical Centre and Harvard Medical School, Boston, MA 02215, USA \\ Correspondence to: Gauthier Bouche. Email: gauthier.bouche@anticancerfund.org
}

\begin{abstract}
Clarithromycin (CAM) is a well-known macrolide antibiotic available as a generic drug. CAM is traditionally used for many types of bacterial infections, treatment of Lyme disease and eradication of gastric infection with Helicobacter pylori. Extensive preclinical and clinical data demonstrate a potential role for CAM to treat various tumours in combination with conventional treatment. The mechanisms of action underlying the anti-tumour activity of CAM are multiple and include prolonged reduction of pro-inflammatory cytokines, autophagy inhibition, and anti-angiogenesis. Here, we present an overview of the current preclinical (in vitro and in vivo) and clinical evidence supporting the role of CAM in cancer. Overall these findings justify further research with CAM in many tumour types, with multiple myeloma, lymphoma, chronic myeloid leukaemia (CML), and lung cancer having the highest level of evidence. Finally, a series of proposals are being made to further investigate the use of CAM in clinical trials which offer the greatest prospect of clinical benefit to patients.
\end{abstract}

Keywords: ReDO project, drug repositioning, clarithromycin, neoplasms, antineoplastic agents, anti-bacterial agents

ecancer 2015, 9:513 DOI: 10.3332/ecancer.2015.513

Copyright: (c) the authors; licensee ecancermedicalscience. This is an Open Access article distributed under the terms of the Creative Commons Attribution License (http://creativecommons.org/licenses/by/3.0), which permits unrestricted use, distribution, and reproduction in any medium, provided the original work is properly cited. 


\section{Introduction}

Clarithromycin (CAM) (or 6-O-methyl erythromycin) is a member of the macrolide antibiotic family together with erythromycin, azithromycin, and roxithromycin. Unlike erythromycin, CAM is acid-stable, has a half-life (five hours) compatible with a twice-a-day administration, and a high and stable bioavailability. CAM has been available as a generic drug worldwide since 2005 [1].

The antimicrobial spectrum of CAM and other macrolides is slightly broader than that of penicillin and as such macrolides are a common substitute for patients allergic to penicillin. In addition, macrolides have been shown to be effective against Legionella pneumophila, Mycoplasma pneumoniae, mycobacteria, some rickettsia, and Chlamydia trachomatis, for which penicillin is not effective. CAM is also used for the eradication of gastric infection with Helicobacter pylori.

The antibacterial effect of macrolides is related to their capacity to inhibit protein synthesis in bacteria. They do so by binding to subunit $50 \mathrm{~S}$ of the bacterial ribosome. Apart from their anti-bacterial activity, macrolide antibiotics have been long known to exhibit a wide range of other pharmacological effects such as the inhibition of mucus hypersecretion and the reduction of the levels of pro-inflammatory cytokines in patients with chronic inflammatory diseases [1].

\section{Dosage}

CAM is usually administered, in tablet or oral suspension form, at a dose of $250 \mathrm{mg}$ twice daily. A dose of $500 \mathrm{mg}$ twice daily is recommended for severe infections or for Helicobacter pylori eradication. $500 \mathrm{mg}$ three times daily is the highest dose approved and was used for Helicobacter pylori eradication before the advent of triple therapy [2]. In children the recommended dose is $7.5 \mathrm{mg} / \mathrm{kg}$ twice daily.

Anti-bacterial treatment with CAM is usually recommended for a duration of one to two weeks. Long-term (from 3 to 12 months) administration of CAM at the dose of $500 \mathrm{mg}$ daily has been shown to be safe and effective in patients with chronic pulmonary disease or chronic sinusitis $[3,4]$. Treatment for four years with $200 \mathrm{mg} /$ day has been trialed in ten patients with diffuse panbronchiolitis with no adverse events except for transient mild diarrhoea which spontaneously resolved after a few days in one patient [5].

\section{Toxicity}

CAM has a well-known toxicity profile thanks to its widespread use as an antibiotic. The most frequent and common adverse reactions are abdominal pain, diarrhoea, nausea, vomiting, and dysgeusia. Other common adverse reactions described are insomnia and rash. These adverse reactions are usually mild in intensity and resolve after treatment discontinuation. All other adverse reactions are uncommon or rare. In particular there are instances where effects on the central nervous system resulting in somnolence and confusion have been described in post-marketing surveillance.

Special caution should be employed when administering CAM to patients with impaired hepatic function or with severe renal insufficiency.

Because of the risk of prolonging the heart's QT interval, CAM should not be given to patients with history of QT prolongation, cardiac arrhythmias, patients with hypokalaemia, or to patients treated with drugs that may result in QT prolongation and cardiac arrhythmias.

Recently, concerns have been raised about possible long-term effects of short CAM usage (e.g. daily for two weeks) on the risk of cardiovascular events and mortality in both patients with stable coronary heart disease and patients without heart disease [6, 7]. Longer intake was also associated with more cardiovascular events. The biological explanation supporting these associations is unclear even though it has been proposed that because clarithromycin may activate macrophages, it could lead to an inflammatory cascade resulting in more vulnerable plaques that over time may lead to acute coronary syndromes or sudden cardiac death by plaque rupture [8].

CAM inhibits cytochrome P450 3A4 (CYP3A4) which is involved in the hepatic metabolism of many drugs. It belongs to the intermediate CYP3A4 inhibition group of antibiotic macrolides, together with roxithromycin [9]. Co-administration of CAM with statins known to be metabolised by CYP3A4 (lovastatin and simvastatin) or with ergotamine or dihydroergotamine is contraindicated. 


\section{Bioavailability}

CAM is acid-stable and has demonstrated excellent and homogeneous bioavailability after oral administration. Following intestinal absorption, it undergoes a rapid first-pass hepatic metabolism. Its main metabolites are 14-(R)-hydroxyCAM, 14-(S)-hydroxyCAM, and N-desmethylCAM. 14-(R)-hydroxyCAM is an active metabolite also responsible for its anti-bacterial effect. CAM's half-life is about five hours whereas 14-(R)-hydroxyCAM's half-life is about seven hours [10-12].

\section{Pre-clinical evidence in cancer-in vitro and in vivo}

Treatment with CAM alone was able to significantly delay the growth of Lewis lung carcinoma and reduce the number of tumour nodules in C57BL/6 mice, with a dose of $10 \mathrm{mg} / \mathrm{kg} / \mathrm{day}$ being most effective in inducing antitumor effects [13]. In a B16BL6 melanoma model, CAM was administered at $50 \mathrm{mg} / \mathrm{kg} /$ day and this reduced the size of melanoma tumours by increasing apoptosis of tumour cells and significantly suppressing pulmonary metastases [14]. In a BALB/c murine B cell lymphoma cell line, CAM induced apoptosis which was demonstrated by the appearance of apoptotic bodies, DNA fragmentation, degeneration and detachment of the cells. No upregulation of Bcl-2 or FasL was seen; however, expression of tumour necrosis factor receptor 1 (TNFR1), caspase-3, -8, -9 suggested that apoptosis was induced through the tumour necrosis factor (TNF) system [15].

In addition to a direct effect on tumour cells, there is evidence that CAM can inhibit tumour-induced angiogenesis in mice [14]. Tumours from mice treated with 50-100 mg/kg CAM had significantly lower vessel density than tumours from the control group in the Lewis lung cancer model and the B16BL6 melanoma model $[14,16]$. Endothelial tube formation was inhibited by CAM in a dose-dependent manner at concentrations greater than 10 microM in vitro [16].

Combination of approved anticancer agents with CAM also showed efficacy. In Lewis lung cancer bearing C57BL/6 mice, CAM administered seven days or more after vindesine or cisplatin significantly enhanced the effect of chemotherapy by increasing natural killer cell activity and CD8+ T cell cytotoxicity, by inducing the well-balanced expansion of helper T cell subsets recovering from immunosuppression caused by the chemotherapy. Intriguingly, this effect was not seen when CAM was administered immediately after chemotherapy [13]. In a melanoma tumour model, CAM potentiated the inhibition caused by cyclophosphamide, cisplatin, doxorubicin, or vindesine, possibly via an anti-angiogenic effect [17]. In rats bearing mammary adenocarcinoma, the death rate was decreased by administration of CAM combined with either carboplatin or cyclophosphamide, while either treatment alone did not affect the death rate. Interestingly, adding CAM to surgery as well as before surgery was beneficial [18]. In vitro, these rats' mammary adenocarcinoma cells expressed lower matrix metalloproteinases-9 (MMP-9), transforming growth factor-beta (TGF- $\beta$ ), and tumour necrosis factor alpha (TNF- $\alpha$ ) levels after CAM treatment [18, 19]. Interleukin-6 (IL-6) was transiently enhanced and decreased to basal levels thereafter, while the tissue inhibitor of metalloproteinase-2 (TIMP-2) expression was not affected [19]. CAM may modulate the tumour microenvironment and influence a tumour's metastatic potential [20, 21]. Furthermore, in tumour-bearing rats, spleen cells from CAM treated animals expressed lower levels of TGF- $\beta$ and IL-6 compared to untreated animals and had a stronger tumour neutralising activity [18].

There is evidence that CAM is a potent and continuous inhibitor of autophagy in both myeloma and chronic myeloid leukaemia cells. At clinically relevant concentrations ( 6 to $50 \mu \mathrm{g} / \mathrm{mL}$ ) CAM inhibits lysosomal function (after fusion of the autophagosomes with the lysosomes) [22]. Thus, CAM could be a potential adjuvant to treatment modalities where autophagy is used by the tumour as an escape mechanism. The proteasome inhibitor bortezomib induces autophagy. The combination of CAM and bortezomib resulted in increased cytotoxicity compared to bortezomib alone [23]. Similar results were obtained using breast cancer cell lines. The combined treatment of bortezomib with CAM enhanced bortezomib induced cytotoxicity, despite the absence of apoptosis induction when CAM was used alone [24]. The apoptosis-inducing effect was further enhanced when vorinostat, a histone deacetylase 6 (HDAC6) inhibitor, was added to bortezomib and CAM [25]. Treatment of chronic myeloid leukemia cells with dasatinib, a tyrosine kinase inhibitor, also induced autophagy. As expected, combining CAM with dasatinib resulted in a significantly decreased percentage of living cells compared to dasatinib alone because of inhibition of late-stage autophagy. Even in a cell line with a clinically known dasatinib-resistant mutation, combination with CAM increased the sensitivity to dasatinib. Whereas clinically relevant concentrations of dasatinib alone had no effect on cell death, the combination with CAM achieved 32\% cell death in these mutant cells [26]. These results are perfectly in line with clinical outcome in advanced CML patients treated with a combination of CAM and dasatinib (described below) [27]. 


\section{Human data}

Numerous clinical trials have been reported with CAM in combination with other drugs in patients with multiple myeloma (MM) and Waldenström's macroglobulinemia (WM) (Table 1). CAM has also been effective against some $H$ pylori-associated cancers such as gastric mucosa-associated lymphoid tissue (MALT) lymphomas, either in a $H$ pylori eradication regimen or as a single agent (Table 2 ). Finally, a handful of trials have demonstrated encouraging results in solid tumours unrelated to $H$ pylori (Table 3 ).

Table 1. Clinical trials in multiple myeloma and Waldenström's macroglobulinemia patients with CAM as cancer treatment.

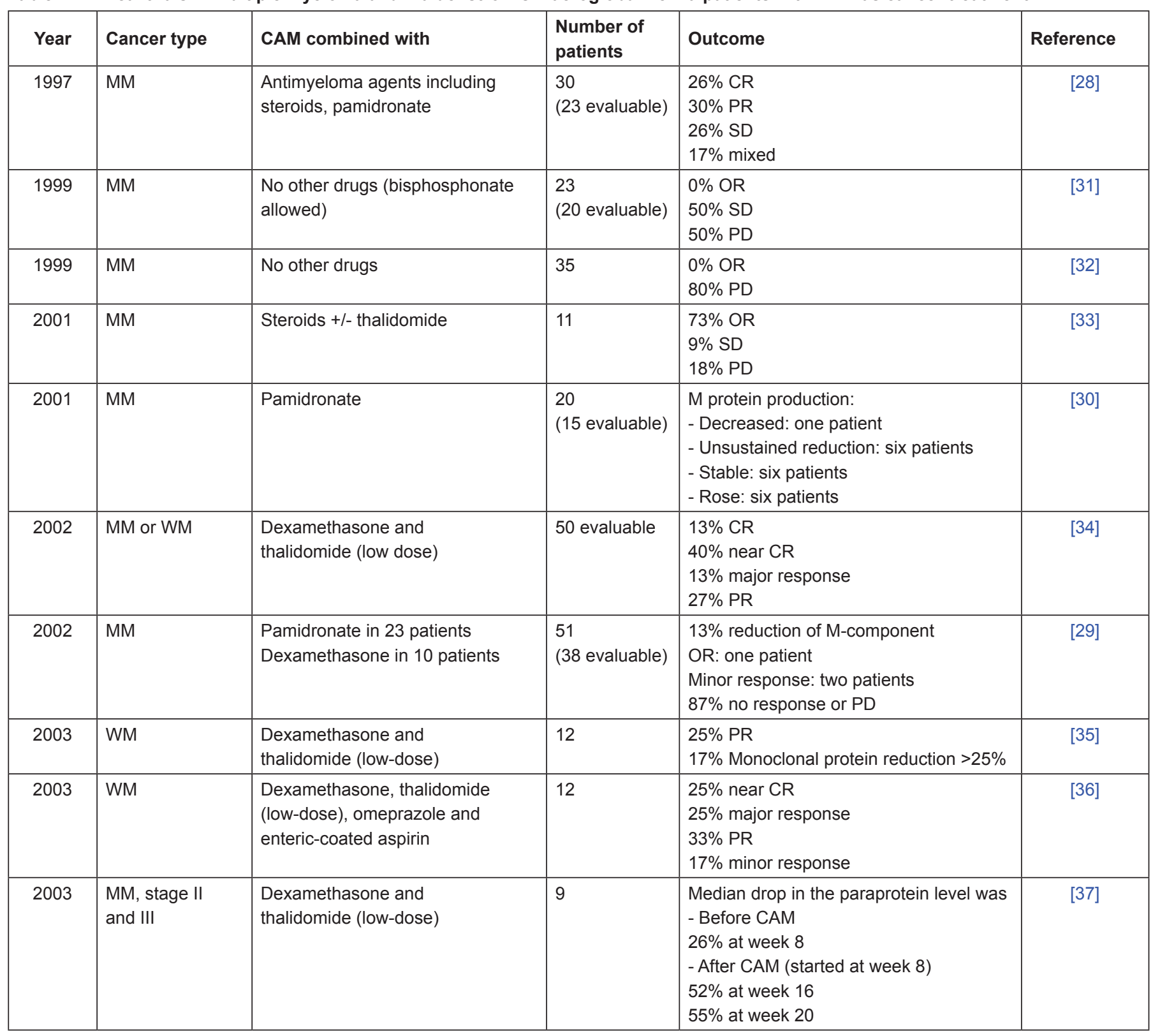


Table 1. Continued.

\begin{tabular}{|c|c|c|c|c|c|}
\hline 2008 & MM & $\begin{array}{l}\text { Dexamethasone, lenalidomide, } \\
\text { aspirin, omeprazole and } \\
\text { trimethoprim/sulfamethoxazole }\end{array}$ & $\begin{array}{l}72 \\
\text { (69 evaluable) }\end{array}$ & $\begin{array}{l}39 \% \text { CR (of which } 31 \% \text { stringent } C R \text { ) } \\
14 \% \text { near CR } \\
21 \% \text { very good PR } \\
17 \% \text { PR } \\
6 \% \text { minor response } \\
\text { Outcomes were compared to matched } \\
\text { controls in } 2010 \text { with the following results: } \\
\text { CR or very good PR: } 74 \% \text { versus } 33 \% \\
\text { Median TTP: } 48.3 \text { versus } 27.5 \text { months } \\
\text { Median PFS } 48.3 \text { versus } 27.5 \text { months } \\
\text { Outcomes were updated in a } 2013 \text { paper: } \\
43 \% \text { CR (of which } 31 \% \text { sCR) } \\
25 \% \text { very good PR } \\
25 \% \text { PR }\end{array}$ & $\begin{array}{c}{[40,41,44,} \\
93]\end{array}$ \\
\hline 2008 & $\begin{array}{l}\text { MM (relapsed } \\
\text { and refractory) }\end{array}$ & $\begin{array}{l}\text { Dexamethasone (low dose), } \\
\text { thalidomide (low-dose or dose } \\
\text { escalation) and biphosponates } \\
\text { (pamidronate or zoledronate) }\end{array}$ & $\begin{array}{l}30 \\
\text { (28 evaluable) }\end{array}$ & $\begin{array}{l}18 \% \text { CR } \\
39 \% \text { good PR } \\
32 \% \text { PR } \\
7 \% \text { Minimal response } \\
4 \% \text { SD }\end{array}$ & [38] \\
\hline 2014 & MM & $\begin{array}{l}\text { Dexamethasone, lenalidomide and } \\
\text { thalidomide (T-BiRd regimen) }\end{array}$ & $\begin{array}{l}26 \\
\text { (25 evaluable) }\end{array}$ & $\begin{array}{l}\text { 8\% stringent CR } \\
36 \% \text { VGPR } \\
36 \% \text { PR } \\
20 \% \text { SD }\end{array}$ & [47] \\
\hline
\end{tabular}

Abbreviations: $\mathrm{MM}=$ multiple myeloma; $\mathrm{WM}=$ Waldenström's macroglobulinemia; $\mathrm{CR}=$ complete response; $\mathrm{pCR}=$ complete pathologic remission; $\mathrm{PR}=$ partial response; $\mathrm{OR}=$ objective response; $\mathrm{SD}=$ Stable disease; $\mathrm{PD}=$ progressive disease; TTP = Time-to-progression;

$\mathrm{PFS}=$ progression-free survival; $=\mathrm{CAM}$ as monotherapy; $>=$ higher; $\mathrm{ASIP}=$ atypical serum immunofixation patterns,

VGPR = very good partial response, $\mathrm{SCR}=$ strigent complete response.

\section{Multiple myeloma and Waldenström's macroglobulinemia (Table 1)}

The first report of the use of CAM in MM patients dates back to 1997 . Durie et al reported at that time a greater than $50 \%$ response rate when 500 mg CAM was administered twice per day [28]. In this study, patients also received dexamethasone. Other groups using CAM as monotherapy could not confirm its potential in MM [29-32]. In a single-arm phase II study, the response to CAM and pamidronate was measured by changes in serum $\mathrm{M}$ protein and urinary $\mathrm{M}$ protein excretion. From the 15 evaluable patients, 12 (80\%) did not show any response [30]. Furthermore, none of the 20 evaluable MM patients had a complete or partial response using standard response criteria after CAM monotherapy and none of the patients with rapidly progressing myeloma at the time of initiation of CAM displayed stable disease on treatment [31].

Similarly, in another study no response was observed in $35 \mathrm{MM}$ patients receiving CAM monotherapy after a median time of eight weeks. In fact, MM progressed in $80 \%$ of cases, requiring other therapeutic approaches [32]. Also in the study by Musto, $33 / 38$ evaluable patients $(87 \%)$ did not show a response as measured by changes in M-component. However, in this study most patients received additional therapy with potential anti-myeloma activity of pamidronate (23 patients) and dexamethasone (ten patients)). Of the few patients showing a response, the strongest responders had received steroids during CAM therapy [29].

In contrast to the low efficacy as a monotherapy, the combination of CAM with steroids, with or without concomitant thalidomide or its analogues, resulted in high response rates, which is in line with the initial results of Durie [28] and the findings of Musto [29]. Vescio et al reported a $73 \%$ response rate during the 2001 annual meeting of the American Society of Haematology, when MM patients were treated with CAM (500 mg twice daily) and steroid therapy with or without thalidomide [33]. Coleman et al reported that the combination of CAM 
with dexamethasone and low-dose thalidomide in patients with MM or WM resulted in a 93\% response rate [34]. Responses in half of the patients with WM who did not respond on thalidomide alone were also observed [35]. In another trial where omeprazole and aspirin were also administered, $83 \%$ of WM patients had a significant response [36].

A trial set up to determine the effect of adding CAM to low-dose thalidomide and dexamethasone on the response rate suggested that CAM potentiates dexamethasone's effect. Addition of CAM to dexamethasone and thalidomide treatment led to a further tumour mass reduction at 16 and 20 weeks in patients whereas less than $50 \%$ response was seen upon induction therapy consisting of dexamethasone alone or in combination with thalidomide [37]. According to Niesvizky et al the addition of CAM would allow a lower dose of dexamethasone while maintaining a high response rate. Indeed, Morris et al reported an overall response rate of $96 \%$, of which $89 \%$ had at least $50 \%$ reduction in paraprotein, in relapsed and refractory myeloma patients when they received CAM combined with low dose dexamethasone and low dose thalidomide [38].

Addition of CAM to treatment with dexamethasone and lenalidomide, one of the immune modulatory drugs (IMiDs) which are structural and functional analogues of thalidomide [39], also resulted in an objective response of $90 \%$ in treatment-naive MM patients in a phase II trial [40]. This treatment was very well tolerated and provided lasting responses. After long-term follow up (6.6 years) the median progression-free survival (PFS) was 49 months and the overall response rate increased to $93 \%$, without an increased incidence of second primary malignancies [41]. This regimen is now known as the BiRd (Biaxin [CAM]/Revlimid [lenalidomide]/[low dose] dexamethasone) regimen. The addition of CAM allowed for a significant reduction of the dexamethasone dose and a higher complete remission response rate compared to a concomitant phase II study with only dexamethasone and lenalidomide treatment [40, 42].

It is possible that low-dose dexamethasone and not the CAM was responsible for the higher remission rates as the trials were not controlled [40,43]. The value of adding CAM to this treatment regimen was therefore investigated by Gay et al in a case-matched study [44]. Patients in the BiRd regimen compared to patients in the Rd regimen had an increased complete or very-good-partial-response rate (73.6\% versus 33.3\%; $P<0.001$ ), and a longer PFS (median values: 48.3 months versus 27.5 months; $P=0.044$ ). Furthermore, a trend towards a better overall survival (OS) was noted with fewer infections and lower levels of dermatological toxicity. On the downside, more instances of thrombocytopenia and steroid-related myopathy were observed in the BiRd regimen compared to Rd. Both the frequency of neutropenia and the rate of thromboembolism were similar in both groups. Despite two toxic deaths in the BiRd group and none in the Rd group, a similar treatment discontinuation occurred in both groups because of adverse events [44].

Additional subgroup analysis indicated that only stage I/II patients benefited from the BiRd regimen, suggesting that CAM makes a difference only in early stage of disease. A randomised phase III study of BiRd versus Rd is planned to verify these results (personal communication with Dr Niesvizky and Dr Mark). Even in one patient with resistance to the Rd regimen, a response was achieved by adding CAM to Rd [45]. This ability of CAM has been recently confirmed by Ghosh who found this in ten (42\%) out of 24 patients with MM based on their response when clarithromycin was added to Rd at the time of progression on Rd [46]. Since BiRd is so well tolerated, and transplant status did not show an effect on PFS or OS, BiRd may provide a less toxic alternative to transplantation [41]. Extending the combinatorial approach by addition of thalidomide to the BiRD regimen (T-BiRD) did not further improve the clinical outcome and was associated with increased non-haematologic toxicity [47].

Besides lenalidomide in the BiRD regimen, other IMiDs have also been used. Rossi et al reported the efficacy of CAM, pomalidomide, and dexamethasone (ClaPD) combination therapy for relapsed or refractory myeloma [47-49].

\section{Other haematological malignancies (Table 2)}

Carella et al reported in 2012 that CAM could also improve clinical outcome of CML patients in combination with a tyrosine kinase inhibitor (TKI), either dasatinib or nilotinib. They serendipitously observed in one patient whose disease was not controlled with dasatinib that after treatment with CAM for otitis/pharyngitis the patient had a complete cytogenetic response. Three other CML patients who had become resistant to TKIs alone, also responded when CAM was added. The Bcr-abl/abl transcript levels fell in all four patients. In three of them, CAM was stopped for various reasons (not because of adverse events), resulting in a relapse and an increase in Bcr-abl/abl transcript levels. In two patients, Bcr-abl/abl transcript levels fell again when CAM was restarted. In the third patient, only the white blood cell count decreased upon recommencing CAM together with dasatinib and the transcript level continued to increase [27]. As of November 2013, all four patients are still alive, with some degree of cytogenetic and molecular remission. Two of them continue to receive CAM on alternate days (personal communication with Dr Carella). 
Table 2. Clinical trials and published cases reporting use of CAM as cancer treatment in haematologic malignancies other than multiple myeloma and Waldenström's macroglobulinemia.

\begin{tabular}{|c|c|c|c|c|c|}
\hline Year & Cancer type & CAM combined with & Number of patients & Outcome & Reference \\
\hline 1997 & Rectal MALT Iymphoma & Omeprazole, amoxicillin & 1 & Regression confirmed pathologically & [125] \\
\hline 1999 & $\begin{array}{l}\text { Low grade rectal MALT } \\
\text { lymphoma }\end{array}$ & Lansoprazole, amoxicillin & $\begin{array}{l}1 \\
\text { (H pylori negative) }\end{array}$ & Complete regression & [62] \\
\hline 1999 & Gastric MALT Iymphoma & $\begin{array}{l}\text { Either with amoxicillin or with } \\
\text { tetracycline }\end{array}$ & $\begin{array}{l}34 \\
\text { (28 H pylori positive) }\end{array}$ & $\begin{array}{l}\text { H pylori-positive patients: } \\
50 \% \text { CR } \\
29 \% \text { PR } \\
36 \% \text { no response } \\
\text { H pylori-negative patients: } \\
100 \% \text { no response }\end{array}$ & [126] \\
\hline 2000 & $\begin{array}{l}\text { Low-grade gastric MALT } \\
\text { lymphoma }\end{array}$ & Omeprazole, amoxicillin & 7 & $100 \%$ complete histologic regression & [127] \\
\hline 2001 & $\begin{array}{l}\text { Low-grade gastric MALT } \\
\text { lymphoma }\end{array}$ & Omeprazole, metronidazole & 97 & $\begin{array}{l}79 \% \text { CR } \\
9 \% \text { PR } \\
11 \% \text { no response }\end{array}$ & [128] \\
\hline 2001 & $\begin{array}{l}\text { High grade B-cell gastric } \\
\text { lymphoma }\end{array}$ & Omeprazole, metronidazole & 8 & $\begin{array}{l}87 \% \mathrm{CR} \\
13 \% \mathrm{PR}\end{array}$ & {$[56]$} \\
\hline 2001 & $\begin{array}{l}\text { High grade gastric MALT } \\
\text { lymphomas }\end{array}$ & Amoxicillin, omeprazole & 16 & $62 \% \mathrm{CR}$ & [53] \\
\hline 2001 & $\begin{array}{l}\text { Primary high grade } \\
\text { gastric DLBCL }\end{array}$ & Amoxicillin, lansoprazole & 1 & no evidence of lymphoma on histology & {$[55]$} \\
\hline 2001 & $\begin{array}{l}\text { Low grade gastric MALT } \\
\text { lymphoma (stage IE and } \\
\text { IIE) }\end{array}$ & Amoxicillin, lansoprazole & $\begin{array}{l}44 \text { (34 H pylori- } \\
\text { positive patients) }\end{array}$ & $\begin{array}{l}43 \% \text { complete histological regression } \\
\text { ( } 56 \% \text { within } H \text { pylori-positive patients) }\end{array}$ & [51] \\
\hline 2001 & Gastric DLBCL & Amoxicillin, omeprazole & 1 & Regression & [58] \\
\hline 2003 & Gastric DLBCL & Lansoprazole, metronidazole & 1 & CR still ongoing after 5.5 years & {$[57]$} \\
\hline 2003 & $\begin{array}{l}\text { Hodgkin's Disease of the } \\
\text { nodular sclerotic type, } \\
\text { stage Ilb }\end{array}$ & Ciprofloxacin & 1 & $\begin{array}{l}\text { Almost complete disappearance of the } \\
\text { pulmonary lesions after three months. } \\
\text { Treatment continued for another five } \\
\text { months. } \\
\text { More than two years later: complete } \\
\text { remission }\end{array}$ & {$[61]$} \\
\hline 2003 & $\begin{array}{l}\text { Low-grade Thyroid MALT } \\
\text { lymphoma }\end{array}$ & Lansoprazole, amoxicillin & 1 & $\begin{array}{l}\text { Complete disappearance of lymphoma } \\
\text { after gastric cancer with } \mathrm{H} \text { pylori } \\
\text { infection treated by } \mathrm{H} \text { pylori } \\
\text { eradication therapy }\end{array}$ & [63] \\
\hline 2004 & $\begin{array}{l}\text { Gastric marginal zone B } \\
\text { cell lymphoma of MALT } \\
\text { (stage I) }\end{array}$ & $\begin{array}{l}\text { Omeprazole and metronidazole } \\
\text { or amoxicillin }\end{array}$ & 95 (90 evaluable) & $\begin{array}{l}62 \% \text { CR } \\
18 \% \text { minimal residual disease } \\
12 \% \text { PR } \\
4 \% \text { no change } \\
2 \% \text { PD }\end{array}$ & {$[50]$} \\
\hline 2005 & $\begin{array}{l}\text { Early-stage, gastric } \\
\text { low-grade transformed } \\
\text { MALT Iymphoma } \\
\text { Early-stage, gastric } \\
\text { high-grade transformed } \\
\text { MALT Iymphoma }\end{array}$ & $\begin{array}{l}\text { Amoxicillin, omeprazole } \\
\text { Amoxicillin, omeprazole }\end{array}$ & $\begin{array}{l}34 \text { (30 patients with } \\
\text { eradicated } H \text { pylori) } \\
24 \text { (22 patients with } \\
\text { eradicated } H \text { pylori) }\end{array}$ & $\begin{array}{l}80 \% \text { CR in patients where } H \text { pylori was } \\
\text { eradicated } \\
64 \% \text { CR in patients where } H \text { pylori was } \\
\text { eradicated }\end{array}$ & {$[54]$} \\
\hline
\end{tabular}


Table 2. Continued.

\begin{tabular}{|c|c|c|c|c|c|}
\hline 2006 & $\begin{array}{l}\text { Duodenal MALT } \\
\text { lymphoma }\end{array}$ & No other drugs & 1 & CR & [64] \\
\hline 2008 & $\begin{array}{l}\text { B-cell gastric lymphoma } \\
\text { (high grade) }\end{array}$ & Omeprazole and amoxicillin & $\begin{array}{l}1 \\
61\end{array}$ & $\begin{array}{l}\text { Complete response } \\
69 \% \text { complete response }\end{array}$ & [52] \\
\hline 2010 & $\begin{array}{l}\text { Extranodal marginal zone } \\
\text { B-cell lymphoma (EMZL) } \\
\text { (relapsed/ refractory) } \\
\text { (stage IE and IV) }\end{array}$ & No other drugs & 13 & $\begin{array}{l}15 \% \mathrm{CR} \\
23 \% \mathrm{PR} \\
31 \% \mathrm{SD} \\
31 \% \mathrm{PD}\end{array}$ & [65] \\
\hline 2010 & $\begin{array}{l}\text { Pulmonary MALT } \\
\text { lymphoma }\end{array}$ & No other drugs & 2 & regression & [66] \\
\hline 2011 & $\begin{array}{l}\text { Follicular B-cell } \\
\text { Iymphoma }\end{array}$ & No other drugs & 1 & $\begin{array}{l}\text { Regression of lymphadenopathy } \\
\text { Decrease in soluble IL-2 receptor }\end{array}$ & [68] \\
\hline 2012 & Advanced CML & Tyrosine kinase inhibitor & 4 & $\begin{array}{l}-25 \% \text { Complete haematologic response } \\
-100 \% \text { of patients had Bcr-abl/abl } \\
\text { transcript level reduction }\end{array}$ & [27] \\
\hline 2012 & $\begin{array}{l}\text { H pylori positive gastric } \\
\text { DLBCLs (de novo and } \\
\text { MALT) stage IE/IIE1 }\end{array}$ & Amoxicillin, omeprazole & $\begin{array}{l}\text { De novo DLBCL: } \\
\text {-chemo: } 30 \\
\text { - antibiotics: } 16 \\
\text { DLBCL (MALT): } 34\end{array}$ & $\begin{array}{l}\text { De novo DLBCL } \\
-69 \% \text { pCR } \\
\text { DLBCL (MALT): } \\
-56 \% \text { pCR }\end{array}$ & [59] \\
\hline 2012 & $\begin{array}{l}\text { H pylori positive gastric } \\
\text { DLBCL (de novo and } \\
\text { MALT) }\end{array}$ & $\begin{array}{l}\text { Tinidazole, metronidazole, } \\
\text { omeprazole }\end{array}$ & $\begin{array}{l}16 \text { DLBCL of which: } \\
\text { - De novo: } 11 \\
\text { - MALT: } 5\end{array}$ & $\begin{array}{l}50 \% \text { CR } \\
19 \% \text { PR } \\
31 \% \text { PD }\end{array}$ & [60] \\
\hline 2012 & DLBCL (stage IV) & Prednisolone & 1 & CR after six months & [69] \\
\hline 2013 & $\begin{array}{l}\text { Follicular B-cell } \\
\text { Iymphoma }\end{array}$ & $\begin{array}{l}\text { Prednisolone, } \\
\text { cyclophosphamide }\end{array}$ & 1 & $\begin{array}{l}\text { Improvement of the para-aortic } \\
\text { lymphadenopathy, hepatomegaly and } \\
\text { ureteral dilatation and decrease in } \\
\text { soluble IL-2 receptor after four months } \\
\text { which improved further after } \\
\text { eight months }\end{array}$ & [70] \\
\hline 2014 & $\mathrm{NHL}$ & $\begin{array}{l}\text { Cyclophosphamide, vincristine } \\
\text { and prednisone (CVP) }\end{array}$ & $\begin{array}{l}60 \text { (55 evaluable) } \\
\text { randomised in CVP } \\
\text { and CVP+CAM }\end{array}$ & $\begin{array}{l}\text { CVP versus CVP+CAM } \\
\text { CR: } 19 \% \text { versus } 32 \%(p=0.04) \\
\text { ORR: } 70 \% \text { versus } 93 \%(p=0.04) \\
2 \text {-year PFS: } 46 \% \text { versus } 75 \%(p=0.02) \\
\text { 2-year OS: } 85 \% \text { versus } 90 \%(p=0.64)\end{array}$ & [67] \\
\hline
\end{tabular}

Abbreviations: MALT = mucosa-associated lymphoid tissue; $C M L=$ chronic myeloid leukaemia; $D L B C L$ = diffuse large B-cell lymphoma;

$\mathrm{NHL}=$ non-Hodgkin lymphoma; $\mathrm{CR}=$ complete response; $\mathrm{pCR}=$ complete pathologic remission; $\mathrm{PR}=$ partial response; OR = objective response;

$\mathrm{SD}=$ Stable disease; $\mathrm{PD}$ = progressive disease; OS = overall survival; PFS = progression-free survival, IL-2 = interleukin-2.

Haematological malignancies associated with a bacterial infection might also benefit from CAM. Development and growth of gastric MALT lymphomas are often associated with a $H$ pylori infection. Eradication of $H$ pylori results in durable tumour regression in the majority of patients with low-grade gastric MALT lymphoma [50, 51]. In patients with high-grade gastric MALT lymphoma or primary gastric diffuse large B-cell lymphoma (DLBCL) durable complete remissions have been described in response to a combination of antibiotics which includes CAM [52-58]. Kuo et al assessed the efficacy of $H$ pylori eradication therapy in patients with stage IE/IIE1 DLBCL of the stomach. The pCR rate was $58 \%$ and was not different between both $H$ pylori positive de novo DLBCL and high-grade transformed MALT lymphoma [59]. Findings of this retrospective study were confirmed in a prospective trial in which $50 \%$ of patients with either de novo DLBCL or high-grade transformed MALT lymphoma achieved a complete response to $H$ pylori eradication only [60]. 
In addition to non-Hodgkin's lymphoma (NHL), there is also a case report of a patient with Hodgkin's disease of the nodular sclerotic type who benefited from antibiotic treatment. CAM combined with another antibiotic, ciprofloxacin, resulted in an almost complete disappearance of the pulmonary lesions. The antibiotics were continued for another five months and more than two years later a complete remission was documented [61].

It is possible that the tumour responses described previously are only because of the antibacterial effect of CAM. Some reports suggest otherwise and propose a direct anti-tumour or immunomodulatory effect of CAM. Regression of low-grade MALT lymphoma of the rectum occurred after $\mathrm{H}$ pylori eradication treatment in a patient negative for $\mathrm{H}$ pylori [62]. A Japanese patient with both low-grade primary thyroid MALT Iymphoma and gastric cancer with $H$ pylori infection achieved a complete disappearance of the lymphoma after $H$ pylori eradication. Immunostaining and PCR revealed no presence of $H$ pylori in the thyroid MALT lymphoma [63]. Furthermore, a woman with MALT lymphoma of the duodenum and no evidence of $H$ pylori infection was treated solely with long-term CAM and achieved a complete remission after six months of treatment [64]. In addition, a 38\% overall response rate was achieved in 13 relapsed/refractory patients with extranodal marginal zone B-cell lymphoma (EMZL) after being exclusively treated with $500 \mathrm{mg}$ of CAM twice a day. The long period between previous antibiotic therapies and trial enrolment together with the lack of evidence of bacterial infections made the authors suggest that the regression of EMZL was because of direct anti-tumour or immunomodulatory effect of CAM [65]. Moreover, two pulmonary MALT lymphoma patients benefited from long-term CAM treatment $(200 \mathrm{mg} /$ day). The first patient showed only a small reduction on conventional treatment (chemotherapy + radiotherapy) and received CAM to treat a sinobronchial syndrome. Regression was observed after a few months and the pulmonary MALT lymphoma was markedly reduced two years after initiation of CAM. The second patient did not receive conventional therapy, and $H$ pylori eradication therapy did not succeed in eradicating $H$ pylori. Despite that, the pulmonary MALT lymphoma almost disappeared after six months of CAM therapy [66]. More recently, in an abstract presented at ASCO in 2014, Saad et al confirmed that the effect of CAM was independent of $\mathrm{H}$ pylori eradication [67]. They randomised 60 patients with indolent non-Hodgkin lymphoma (NHL) to receive either CVP (cyclophosphamide, vincristine, and prednisone) or CVP plus CAM (500 mg twice a day D5-D18) every 21 days. MALT lymphoma patients were eligible after confirmation of $H$ pylori negativity. Complete response rate, objective response rate, and two-year PFS were significantly better in the CAM arm with $32 \%$ versus $19 \%, 93 \%$ versus $70 \%$, and $75 \%$ versus $46 \%$ respectively. Two-year OS was not significantly different between arms (90\% versus $85 \%$ ). A greater decrease in vascular endothelial growth factors (VEGF) after two cycles was observed in the CAM arm.

Ohe $\mathrm{M}$ et al described several cases in which it is considered likely that CAM contributed to a direct anti-tumour effect. In a case of follicular B-cell lymphoma, the lymphadenopathy regressed and the levels of soluble IL-2 receptor decreased following CAM treatment [68]. Combining CAM (800 mg/day) with a steroid, prednisolone, to treat a patient with diffuse large B-cell lymphoma resulted in a complete response after six months [69]. Also, 400 mg CAM, twice daily, combined with prednisolone and cyclophosphamide was successful in improving para-aortic lymphadenopathy, hepatomegaly, and ureteral dilatation at four months in a patient with follicular B-cell lymphoma. Soluble IL-2 receptor decreased. Further improvement was observed at eight months [70].

\section{Solid tumours (Table 3)}

In addition to MM and lymphomas, there is evidence of anticancer activity of CAM in solid tumours. In a randomised trial in 49 patients with advanced lung cancer-42 with non-small cell lung cancer (NSCLC) and 7 with small cell lung cancer (SCLC)-reported in 1997, Mikasa et al found that the 25 patients treated with maintenance CAM (200 mg b.i.d.), commencing on the first post-discharge hospital visit and continuing for as long as they could tolerate it, had a significantly longer survival (median of 395 days) than patients who did not receive CAM (median of 256 days). The benefit seemed to only occur in NSCLC patients where survival time was almost doubled (median survival of 535 versus 277 days for NSCLC CAM patients versus NSCLC control patients). Patients receiving CAM were also able to stay at home for longer periods than those in the non-CAM group. They remained in good condition for a long period and had a good appetite; consequently, they gained weight during treatment [71]. These results were confirmed in a follow-up study in NSCLC from the same group and results were ascribed to reduced serum IL-6 levels after CAM treatment. Patients whose serum IL-6 levels decreased survived longer, irrespective of the histological type of disease, and the decrease in IL-6 statistically correlated with the increase in body weight [72]. Unfortunately, it seems that no further research has been published in NSCLC with CAM even though we have identified ten papers published in Japanese in the late 1990 s and early 2000s. 
Table 3. Clinical trials in patients with solid tumours with CAM.

\begin{tabular}{|c|c|c|c|c|c|}
\hline Year & Cancer type & CAM combined with & $\begin{array}{l}\text { Number of } \\
\text { patients }\end{array}$ & Outcome & Reference \\
\hline 1997 & $\begin{array}{l}\text { Lung stage Illa, } \\
\text { IIIb, IV (NSCLC } \\
\& \text { SCLC) }\end{array}$ & $\begin{array}{l}\text { No other drugs } \\
\text { (Prior chemo or radiation therapy } \\
\text { or both) }\end{array}$ & $\begin{array}{l}49 \\
\text { - CAM: } 22 \text { NSCLC \& } \\
3 \text { SCLC } \\
\text { - no CAM: } 20 \text { NSCLC } \\
\text { \& } 4 \text { SCLC }\end{array}$ & $\begin{array}{l}\text { NSCLC: increased median survival time } \\
\text { SCLC: no significant difference in median } \\
\text { survival time }\end{array}$ & [71] \\
\hline 2000 & $\begin{array}{l}\text { Breast cancer } \\
\text { (mastectomy) }\end{array}$ & No other drugs & $\begin{array}{l}54 \\
-28 \text { CAM } \\
-26 \text { no CAM }\end{array}$ & $\begin{array}{l}\text { Reduced change in temperature, heart \& } \\
\text { respiratory rate and monocyte count after } \\
\text { surgery }\end{array}$ & [74] \\
\hline 2001 & $\begin{array}{l}\text { Lung stage IIla, } \\
\text { IIIb, IV (NSCLC) }\end{array}$ & $\begin{array}{l}\text { No other drugs } \\
\text { (Prior chemo or radiation therapy } \\
\text { or both) }\end{array}$ & $\begin{array}{l}47 \\
\text { - CAM: } 33 \text { patients } \\
\text { - No CAM: } \\
14 \text { patients }\end{array}$ & Not indicated & [72] \\
\hline 2004 & $\begin{array}{l}\text { Lung stage I, } \\
\text { II, IIla }\end{array}$ & $\begin{array}{l}\text {-control: Flomoxef } \\
\text {-CAM: flomoxef + CAM }\end{array}$ & $\begin{array}{l}\text { - Control: } 16 \text { patients } \\
\text { - CAM: } 10 \text { patients }\end{array}$ & Significant reduced duration of SIRS & [73] \\
\hline
\end{tabular}

Abbreviations: NSCLC: non-small-cell lung cancer; SCLC = small-cell lung cancer; CAM = clarithromycin;

SIRS = Systemic inflammatory response syndrome.

CAM has also been shown to decrease acute inflammation after surgery. Both the incidence and duration of the postoperative systemic inflammatory response syndrome (SIRS) was significantly reduced in lung cancer patients receiving CAM compared to control [73]. Also the inflammatory response after mastectomy was modulated by CAM, as reflected by differences in temperature, heart rate, respiratory rate, and monocyte count between the treatment and control group. Furthermore, CAM had the additional benefit of decreasing the intensity and duration of pain from mastectomy [74].

\section{Clinical trials}

On 3 November 2014, a search for ongoing trials using CAM as an anticancer agent in the treatment of cancer patients in clinicaltrials.gov revealed three trials in multiple myeloma (NCT01745588, NCT01559935, and NCT02248428) and three trials in H pylori associated malignancies (NCT01516606, NCT00327132, NCT01264822). On the same date, no trial was registered to treat cancer patients with other members of the macrolide antibiotic class currently available on the market (erythromycin, azithromycin, roxithromycin).

\section{Mechanism of action}

There is a wealth of information describing the possible effects of CAM. When compiling information from the clinical trials and from the pre-clinical experiments, it is reasonable to hypothesise that several mechanisms of action explain the anticancer activity of CAM and that the mechanisms involved depend on the type of cancer and on the drugs it is combined with. The principal mechanisms of action are described below.

\section{Direct anti-tumour effect}

Whether or not CAM has direct antineoplastic effects may depend on the tumour type. In a rat model, no direct effect on mammary adenocarcinoma was observed [18]. However, lymphoma tumour regression after CAM treatment independent of the eradication of $H$ pylori suggests direct anti-tumour activity of CAM on lymphoma cells [64-66]. Indeed, CAM directly induces apoptosis in a murine 
B cell lymphoma cell line, via the TNF system [15]. Macrolides can also induce apoptosis of human peripheral blood derived lymphocytes [75]. In addition, in human blood mononuclear cells it is shown that CAM inhibits NF-kB activation induced by TNF- $\alpha$ [76]. NF-kB regulates gene expression, including upregulation of the anti-apoptotic genes bcl-2 and Bcl-xL. Furthermore, aberrant nuclear expression of NF-KB was generally detected in both the large cells and their low-grade counterparts within the $H$ pylori-independent tumours [77]. This downregulation of antiapoptotic genes by CAM (through NF-kB) might in part explain the effect of long-term use of CAM on tumour cells despite eradication of the infection or even in the absence of infection. The majority of DLBCL and gastric MALT cases show bcl-2 expression $[78,79]$. In addition, some investigators have shown in mice that Bcl-xL might play a role in the pathogenesis of B-cell MALT lymphoma developed from chronic infection with Helicobacter species [80, 81]. At least in activated lymphocytes, the downregulation of Bcl-xL has been reported as the mechanism by which CAM induces apoptosis [82].

In addition to the NF-KB pathway, other pathways could also be involved. Some bacteria including, $H$ pylori, can dysregulate the Wnt/ $\beta$-catenin pathway. Given the contribution of the Wnt/ $\beta$-catenin pathway in the carcinogenic process and the ability of some antibiotics (rapamycin, streptonigrin) to inhibit this, it is conceivable that CAM also interacts with this intracellular signalling pathway. To the best of our knowledge, no research has been done thus far on the influence of CAM on the $\mathrm{Wnt} / \beta$-catenin signalling pathway. In this connection, Semino-Mora et al reported that $\beta$-catenin levels were decreased in the cytoplasm, the cell nuclei, and the mucin-associated cells while $\beta$-catenin levels within membranes increased in pseudomyxoma peritonei patients after $H$ pylori eradication treatment containing CAM, providing potential protection against cell detachment, cellular invasion, and metastasis [83].

For the control of cellular proliferation, extracellular signal-regulated kinase (ERK) plays an important role [84, 85]. Modulation of ERK phosphorylation by CAM at physiologic concentrations retards cell proliferation of a normal bronchial epithelial cell line, by preventing cells passing from G1 into S phase of the cell cycle [86]. Several oncogenes can constitutively activate ERK, and uncontrolled activation of ERK can lead to malignant transformation [87, 88]. In NSCLC, ERK1/2 is activated and associated with advanced tumours [89]. The antitumor effect seen in NSCLC patients could therefore be partly mediated via modulation of ERK by CAM.

For multiple myeloma cells, IL-6 is an important cytokine with regard to proliferation, survival, drug resistance, and migration [90]. Since CAM inhibits IL-6 secretion [72], this might exert a direct anti-cancer effect in MM. However, inhibition of one single growth factor is unlikely to be sufficiently potent to obtain a clinical benefit for multiple myeloma [30-32].

\section{Synergism with approved anticancer drugs}

\section{Dexamethasone}

Despite the poor clinical outcome after CAM as monotherapy in myeloma patients, CAM has an added value when combined with other treatment modalities such as thalidomide or its analogues, and steroids [44]. Such combinations have been used in more than ten different trials [33-35, 37, 38, 40, 41, 44, 47, 91-93]. As such, CAM augments the response to dexamethasone when given alone or in combination with thalidomide to patients with MM [37, 94].

However, the exact mechanism of this synergism is unknown. One possible explanation is that CAM slows the hepatic clearance of dexamethasone and other drugs used to treat MM as it does for other drugs metabolised by CYP3A4. Unfortunately, to the best of our knowledge, a direct comparison on the effect of CAM on dexamethasone metabolism has not been done and studies of interaction of CAM with other glucocorticoids (prednisolone and methylprednisolone) showed interaction with one but not the other [95]. There could be other reasons for this synergism. In one in vitro study, lymphocytes derived from CAM-treated asthma patients had a significant enhanced sensitivity to suppression by dexamethasone in the presence of CAM [96] suggesting a possible synergism in the modulation of immune cells subtypes. Furthermore, glucocorticoids (dexamethasone) induce apoptosis of lymphoid cells, which is attenuated by bcl-2. As CAM down-regulates bcl-2 expression by inhibiting NF-kB activation [76], CAM combined with glucocorticoids may synergise in inducing apoptosis.

In addition, both dexamethasone and CAM lead to suppression of inflammatory cytokines. Influencing inflammation to reduce tumour growth is discussed in more detail below. Glucocorticoids inhibit IL-8 through the glucocorticoid response element or the NF-KB binding site. CAM indirectly acts on the AP-1 binding site in the IL-8 promoter to repress IL-8 [97]. 
Recent findings indicate that glucocorticoids not only cause apoptotic cell death [98] but also induce autophagy resulting in tumour cell death in haematologic malignancies [99]. It has been suggested that adding other drugs inducing or targeting autophagy could lead to more tumour cell death, providing another explanation of the synergism between dexamethasone and CAM in MM [99].

To conclude on dexamethasone and CAM, the use of different mechanisms might underlie the additional value of combining dexamethasone and CAM.

\section{Therapies inducing autophagy}

The autophagy process provides tumour cells alternative sources of energy during periods of metabolic stress or starvation to maintain cellular homeostasis and survival [100]. Autophagy is also upregulated during extracellular matrix (ECM) detachment which is required for metastasis [101]. In MM cells, CAM contributed to the anti-tumour effect by halting the autophagy process at clinically relevant concentrations of $6-50 \mu \mathrm{g} / \mathrm{mL}[22,23]$. The combination of CAM and the proteasome inhibitor, bortezomib targets respectively the autophagy-lysosome system and the ubiquitin-proteasome system for protein degradation. This enhances endoplasmatic reticulum stress-mediated apoptosis by increased expression of the proapoptotic transcription factor CHOP (CADD153) in MM cell lines [23]. The additional benefit of CAM with TKIs could also be ascribed to the inhibition of autophagy used by cells to resist and escape treatment [26]. Many current cancer treatment modalities such as radiotherapy and chemotherapy also induce autophagy which promotes tumour dormancy and facilitates re-growth [100]. It can be hypothesised that CAM could overcome, or delay, resistance to conventional treatment via the inhibition of the autophagic response of cancer cells [26].

Concerns have recently been raised with regard to exploiting the autophagy inhibition mechanism that CAM seems to possess, especially in strategies that aim to also exploit the immune system. Scheduling of CAM treatment in relation to chemotherapy may be critical. It is possible that a very short course of CAM just at the time of chemo or radiation therapy might increase cell kill by inhibition of autophagy. However, allowing autophagy to take place may be critical for antigen presentation by dendritic cells [102], which occurs a few days after chemotherapy-induced cell kill. Thus CAM administration may be best avoided for a week or two following cell kill. On the other hand, autophagy blockade aids NK cell lysis, so that late institution of CAM treatment would serve this purpose [103]. The paper by Hamada et al emphasises the fact that CAM treatment was beneficial only when started one week post chemotherapy [13] and CAM treatment was instituted by Mikasa et al about a month after chemo and radiation therapy was over [71].

\section{Modulation of tumour environment}

\section{Immune modulating and anti-inflammatory action}

Macrolide antibiotics are known to have anti-inflammatory effects [1]. Anti-inflammatory effects relevant to cancer have been suggested by the capacity of CAM to reduce acute inflammation after mastectomy or lung cancer surgery $[73,74]$.

Cancer and chronic inflammation are closely intertwined. Chronic inflammation is known to drive tumour growth. Cytokines produced by immune cells, the tumour, and its environment are key regulators of the inflammatory response, able to either drive (pro-inflammatory) or suppress (anti-inflammatory) inflammation. CAM modulates ERK1/2 phosphorylation in bronchial epithelial cells and inhibits the activation of NF-KB and AP-1, two important transcription factors in inflammation [76, 97, 104, 105]. In this way CAM temporarily suppresses the production of the pro-inflammatory cytokines IL-1 $\alpha$, IL-1 $\beta$, interleukin-1 receptor antagonist (IL-1RA), granulocyte-colony stimulating factor (G-CSF), granulocyte macrophage colony stimulating factor (GM-CSF), IL-6, IL-8 and TNF- $\alpha$ in human monocytes, eosinophils, monocytic leukemia cell lines, and bronchial epithelial cells [104-108]. A decrease in IL-6 was confirmed in serum of lung cancer patients [72]. In contrast, CAM enhanced IL-10 secretion by monocytes [106]. Inhibition of IL-8 by CAM has been shown to be temporary with levels increasing thereafter, to decrease again later to basal pre-inflammatory levels [105]. This immunomodulatory action of CAM and other macrolides resulting in an initial and short-lived increase in inflammation followed by a sustained decrease of cytokine production and secretion to normal levels is conceptualised as 'resetting the circuits' [1]. Furthermore, in chronic obstructive pulmonary disease (COPD) patients and patients with cystic fibrosis, a decrease of pro-inflammatory cytokines was seen in sputum and serum after CAM treatment [109, 110]. 
IL-8 is a chemokine produced by several cell types and attracts inflammatory cells to the site of infection. IL-8 is also a promoter of angiogenesis. It is believed to be partly responsible for the maintenance of chronic inflammation in gastritis caused by $H$ pylori [111-113]. In order for IL-8 to be secreted in response to $H$ pylori by a gastric cancer cell line (MKN45), the AP-1 and NF-KB binding sequences in the IL-8 promoter are required [114]. Also IL-8 secretion upon TNF- $\alpha$ and IFN- $\gamma$ stimulation requires the same sequences [115]. CAM inhibits NF-KB activation and indirectly inhibits the AP-1 binding in the promoter region of IL-8, as found in epithelial, monocytic, and lymphocytic cell lines, and peripheral blood mononuclear cell (PBMC) [76, 97, 104]. As the mechanism for IL-8 transcription is similar in these cell types and the MKN45 gastric cancer cell line, and macrolides can enter eukaryotic cells without receptors the previous results can possibly be extrapolated to gastric cancer cells. This means that inflammation (TNF- $\alpha$ and IFN- $\gamma$ ) can maintain IL-8 secretion by gastric cancer cells and that this can become inhibited by CAM by inhibiting NF-KB activation and AP-1 binding in the IL-8 gene promoter region in gastric cancer cells. These findings suggest that the additional value of CAM in gastric cancers is dampening the chronic inflammatory tumour microenvironment.

CAM also modulates the immune system by other mechanisms. When combined with glucocorticoids and theophylline, it almost completely abolishes the survival effect of IL-5 on eosinophils [116]. In a mouse model of bleomycin-induced lung injury, CAM reduced the expression of the vascular adhesion molecule 1 (VCAM-1), affecting leukocyte migration to the site of inflammation [117]. In vitro after mitogen stimulation of T cells, CAM markedly inhibited T cell proliferation and IL-2 production [118]. The Th1 cytokines IL-2 and TNF- $\alpha$ were inhibited more markedly than the Th2 cytokines [119]. These in vitro results are in contrast to the results obtained in cystic lung fibrosis patients, in whom peripheral blood lymphocytes showed a sustained increased proliferation after CAM treatment. Prolonged CAM treatment in these patients showed reduction of cytokines in sputum and serum, concurrent with a switch from Th2 to Th1 type response measured by the IFN-y/IL-4 ratio [110]. Williams et al reported that CAM decreased dose-dependently IL-4 secretion from human mononuclear cells stimulated with phorbol myristate acetate and ionomycin, such that the Th1/Th2 ratio increased [120]. If this effect of CAM holds true in the presence of a tumour, it could have an immune stimulatory effect against the tumour. In murine bone-marrow derived dendritic cells (DCs), CAM upregulated the expression of CD80, a T cell co-stimulatory molecule and decreased IL-6 production by DCs, without increasing IL-10 production. Stimulated naïve splenic T cells by these DCs showed reduced IL-2 levels [121]. Finally, IL-6 is known to stimulate the production of myeloid derived suppressor cells (MDSCs), a powerful class of immunosuppressive cells. CAM may therefore decrease MDSCs in the tumour environment though this is speculative at the moment.

\section{Anti-angiogenesis}

Besides influencing the secretory factors of epithelial cells and immune cells in the tumour microenvironment, animal models have shown that CAM also targets the tumour microenvironment by inhibiting tumour-induced angiogenesis [14, 16, 122]. The recent randomised trial by Saad et al in NHL indicates that adding CAM to a CVP regimen was able to reduce soluble vascular endothelial growth factor (sVEGF) level more than CVP alone. As these findings correlated with a clinical benefit in terms of response and PFS, they indicate that the effect of CAM involves the VEGF pathway [67].

CAM could have an impact on the same core cancer-associated biological processes as thalidomide and its analogues. These also modulate inflammatory cytokines, T cells, adhesion, expression of adhesion molecules, and angiogenesis [39]. To conclude this part on the mechanism of action, CAM acts on tumour-associated inflammation, angiogenesis, signal transduction pathways, growth signals, autophagy, and metastasis.

\section{Our Take}

\section{Next steps}

Based on the evidence summarised in Table 4 it is our contention that human clinical trials of CAM in certain types of cancer is warranted. The known pharmacokinetics, relatively low toxicity, low cost, and strong pre-clinical and clinical evidence make this an ideal candidate for repurposing. 
Table 4. Summary of the pre-clinical and clinical evidence available for the use of CAM as an anticancer agent, per cancer type.

\begin{tabular}{|l|c|c|c|}
\hline Cancer type & In Vitro & In Vivo & Case report/Trial \\
\hline Multiple Myeloma & {$[22,23]$} & & {$[28-34,37,38,40,41,44,47,93]$} \\
\hline CML & {$[26]$} & & {$[27]$} \\
\hline $\begin{array}{l}\text { Waldenström's } \\
\text { macroglobulinemia }\end{array}$ & & & {$[34-36]$} \\
\hline Lung (NSCLC) & {$[16]$} & {$[13]$} & {$[71-73]$} \\
\hline Breast & {$[19,24,25]$} & {$[18,21]$} & \\
\hline Melanoma & & {$[14,17]$} & {$[27,50-70,125-129]$} \\
\hline Lymphoma & {$[15]$} & & \\
\hline
\end{tabular}

\section{Multiple myeloma}

It seems that interest in CAM as an anticancer agent has taken off for MM and WM. However, no randomised trials have been performed and the most urgent next step in MM is to put CAM to the test in a randomised trial. This should happen soon thanks to the continuous efforts of Dr Tomer Mark, Dr Morton Coleman, Dr Ruben Niesvizky, and their colleagues at Weill Cornell Medical College and the New York Presbyterian Hospital (NY, USA). Also important would be to conduct pharmacokinetics/pharmacodynamics studies and other ancillary studies (cytokines, etc.) to document and understand how CAM works in the BiRd regimen.

\section{$H$ pylori-associated lymphomas}

The value of CAM in eradicating $H$ pylori was established 20 years ago. The complete and long-lasting responses in $H$ pylori-associated malignancies after bacterial eradication are more recently observed. The most important step is to identify precisely patients who could benefit from a simple $H$ pylori eradication in gastric DLBCL and MALT lymphoma. In 2001, Morgner reported that even high-grade MALT lymphomas, which are thought to have become independent of $H$ pylori, could respond to $H$ pylori eradication [56]. More than ten years later, clinicians started to identify patients who actually benefit from this simple approach and are providing reassuring data about the effectiveness of rescue strategies in case of failure of $H$ pylori eradication $[59,60]$. It will be important to gather additional data within clinical trials about the effectiveness and safety of this strategy.

\section{Other B-cell lymphomas}

As several authors have reported responses in lymphomas independent of $H$ pylori [61-67], the most important action for further evaluating the potential of CAM in these lymphoma subtypes is to identify settings where CAM would be of help. Two situations come immediately to mind: when no other standard or experimental options are available or in patients with indolent disease in whom the balance between benefit and risk of cytotoxic treatment is unfavourable. In the latter situation, CAM could be tested as an alternative in a clinical trial.

\section{Solid tumours}

Finally, more research is desperately needed in solid tumours. To the best of our knowledge, there has been no attempt in Japan or anywhere else to confirm the survival benefit reported by Mikasa et al in 1997 in patients with NSCLC [71]. Several Japanese groups were active in the late 1990's and early 2000's but it seems that interest has waned since CAM became a generic drug in 2005. Currently, there are no clinical trials registered. We are aware of one trial under preparation by Prof. Albrecht Reichle (Regensburg, Germany) in patients with NSCLC where CAM will be administered together with a metronomic chemotherapy and pioglitazone (personal communication with Prof. Albrecht Reichle).

The evidence suggests that cancer types to take to human trials include:

- NSCLC in combination with standard first-line chemotherapy, based on Mikasa's findings [71] and the documented benefit of using CAM in COPD patients [4]. However, because of the concerns of a possible negative impact of inhibiting autophagy on the role of the immune system [102, 103], it may be best to not administer CAM with chemotherapy (or radiotherapy). It might be best to give it one to two weeks following cell kill to allow optimal antigen presentation. 
- SCLC in combination with chemotherapy, also based on COPD data and because the numbers of SCLC patients in the trial reported by Mikasa were too low to draw any conclusion, taking the caution mentioned above about the timing of CAM administration.

- CML in patients developing resistance to second generation TKIs as observed by Carella [27];

- Melanoma in the following settings:

o In patients with BRAF-mutated tumours together with BRAF inhibitors to delay resistance as recent work have shown that resistance to BRAF inhibitors could be overcome by targeting autophagy in BRAF (V600E) melanoma [123], as well as in other BRAF (V600E)-mutated tumours [124]. CAM could be an alternative to chloroquine in targeting autophagy.

o In patients progressing or not responding to checkpoint blockade agent based upon the immunomodulatory activity of CAM.

- Other advanced solid tumours resistant to conventional treatment. The use of metronomic schedule of chemotherapy together with CAM in these populations could be tested with the intention of synergising the immunomodulatory and anti-angiogenic effects of both interventions. The use of pharmacokinetics, biomarkers (especially immune and angiogenic ones), and dynamic imaging in such trials would be very informative to document the biological effects induced by this combination.

\section{Conclusion}

Besides interfering with the protein synthesis, by which CAM exerts its antibacterial function, CAM also affects signalling pathways and transcription factors, drug pharmacokinetics, autophagy, immune function and inflammation, and angiogenesis. These features of CAM can be exploited to make tumour cells more prone to apoptosis and reduce escape mechanisms. As such, CAM can be used as a supportive drug in conventional cancer treatments and can even be used as a monotherapy for some tumours.

The anti-tumour activity of CAM has been demonstrated in tumour cell lines and mouse models. Clinical trials have confirmed the potential of CAM in NSCLC and lymphoma, even as a single treatment. In combination with other treatments CAM has proven effective in early stage multiple myeloma, and Waldenström macroglobulinemia. Larger randomised trials to establish CAM's anti-tumour potential are needed as well as more insights into the pharmacokinetics of CAM in combination regimens. Furthermore, better identification of patients and tumours benefiting from CAM would be a leap forward in the use of this low-cost drug. Based on the available data, it is also worth attempting to extend the benefit of CAM to other tumour types such as CML, SCLC, melanoma, and breast cancer, and clinical trials to investigate these are warranted.

\section{Conflicts of interests}

The authors declare that they have no conflict of interest. All the authors are associated with not-for-profit organisations that aim to repurpose drugs for oncology treatments.

\section{Author contributions}

Primary authors: An MT Van Nuffel and Gauthier Bouche. Contributing authors: Vidula Sukhatme, Pan Pantziarka, Lydie Meheus, and Vikas P. Sukhatme. All authors have read and approved the final manuscript.

\section{Acknowledgments}

The authors would like to thank Ruben Niesvizky, Tomer Mark, Angelo Michele Carella, and Albrecht Reichle. 


\section{References}

1. Kanoh S and Rubin BK (2010) Mechanisms of action and clinical application of macrolides as immunomodulatory medications Clin Microbiol Rev 23(3) pp 590-615 DOI: 10.1128/CMR.00078-09 PMID: 20610825 PMCID: 2901655

2. Schwartz $\mathrm{H}$ et al (1998) Triple versus dual therapy for eradicating Helicobacter pylori and preventing ulcer recurrence: a randomized, double-blind, multicenter study of lansoprazole, clarithromycin, and/or amoxicillin in different dosing regimens Am J Gastroenterol 93(4) pp 584-90 DOI: 10.1111/j.1572-0241.1998.169 b.x PMID: 9576452

3. Varvyanskaya A and Lopatin A (2014) Efficacy of long-term low-dose macrolide therapy in preventing early recurrence of nasal polyps after endoscopic sinus surgery Int Forum Allergy Rhinol 4(7) pp 533-41 DOI: 10.1002/alr.21318 PMID: 24659566

4. HerathSC and Poole P (2013) Prophylactic antibiotic therapy for chronic obstructive pulmonary disease (COPD) Cochrane Database Syst Rev 11 pp CD009764 PMID: 24288145

5. Kadota J et al (2003) Long-term efficacy and safety of clarithromycin treatment in patients with diffuse panbronchiolitis Respir Med 97(7) pp 844-850 DOI: 10.1016/S0954-6111(03)00042-8 PMID: 12854636

6. Gluud C et al (2008) Clarithromycin for 2 weeks for stable coronary heart disease: 6 -year follow-up of the CLARICOR randomized trial and updated meta-analysis of antibiotics for coronary heart disease Cardiology 111(4) pp 280-7 DOI: 10.1159/000128994 PMID: 18451646 PMCID: 2820332

7. Schembri S et al (2013) Cardiovascular events after clarithromycin use in lower respiratory tract infections: analysis of two prospective cohort studies BMJ (Clinical research ed) $\mathbf{3 4 6}$ pp f1235

8. Winkel $\mathrm{P}$ et al (2011) Excess sudden cardiac deaths after short-term clarithromycin administration in the CLARICOR trial: why is this so, and why are statins protective? Cardiology 118(1) pp 63-7 DOI: 10.1159/000324533 PMID: 21447948

9. Zhanel GG et al (2001) Review of macrolides and ketolides: focus on respiratory tract infections Drugs 61(4) pp 443-98 DOI: 10.2165/00003495-200161040-00003 PMID: 11324679

10. Chu SY, Deaton R and Cavanaugh J (1992) Absolute bioavailability of clarithromycin after oral administration in humans Antimicrob Agents Chemother 36(5) pp 1147-50 DOI: 10.1128/AAC.36.5.1147 PMID: 1387301 PMCID: 188854

11. Benninger $\mathrm{P}$ et al (2004) A comparative clarithromycin bioavailability study: determination of clarithromycin and 14-(R)hydroxyclarithromycin under fasting and fed conditions Int J Clin Pharmacol Ther 42(6) pp 342-9 DOI: 10.5414/CPP42342 PMID: 15222728

12. Zuckerman JM et al (2011) Review of macrolides (azithromycin, clarithromycin), ketolids (telithromycin) and glycylcyclines (tigecycline)Med Clin North Am 95(4) pp 761-91 viii DOI: 10.1016/j.mcna.2011.03.012 PMID: 21679791

13. Hamada K et al (2000) Adjuvant effect of clarithromycin on chemotherapy for murine lung cancer Chemotherapy 46(1) pp 49-61 DOI: $\underline{10.1159 / 000007256}$

14. Yatsunami J et al (1999) Antiangiogenic and antitumor effects of 14-membered ring macrolides on mouse B16 melanoma cells Clin Exp Metastasis 17(4) pp 361-7 PMID: 10545023

15. Ohara T et al (2004) Antibiotics directly induce apoptosis in B cell lymphoma cells derived from BALB/c mice Anticancer Res 24(6) pp 3723-30

16. Yatsunami $\mathrm{J}$ et al (1997) Clarithromycin is a potent inhibitor of tumor-induced angiogenesis Res Exp Med (Berl) Zeitschrift für die gesamte experimentelle Medizin einschliesslich experimenteller Chirurgie 197(4) pp 189-97 DOI: 10.1007/s004330050068 PMID: $\underline{9440137}$ 
17. Yatsunami $\mathrm{J}$ et al (1999) Roxithromycin and clarithromycin, 14-membered ring macrolides, potentiate the antitumor activity of cytotoxic agents against mouse B16 melanoma cells Cancer Lett 147(1-2) pp 17-24 DOI: 10.1016/S0304-3835(99)00258-X

18. Sassa K et al (1999) Therapeutic effect of clarithromycin on a transplanted tumor in rats Antimicrobial Agents Chemother 43(1) pp 67-72

19. Sassa K, Mizushima Y and Kobayashi M (1999) Differential modulatory effects of clarithromycin on the production of cytokines by a tumor Antimicrob Agents Chemother 43(11) pp 2787-9 PMID: 10543765 PMCID: 89561

20. Nakajima $M$ et al (1993) Serum and plasma $M(r)$ 92,000 progelatinase levels correlate with spontaneous metastasis of rat 13762NF mammary adenocarcinoma Cancer Res 53(23) pp 5802-7 PMID: $\underline{8242639}$

21. Welch DR, Fabra A and Nakajima M (1990) Transforming growth factor beta stimulates mammary adenocarcinoma cell invasion and metastatic potential Proc Natl Acad Sci U.S.A. 87(19) pp 7678-82 DOI: 10.1073/pnas.87.19.7678 PMID: 2217201 PMCID: $\underline{54811}$

22. Nakamura M et al (2010) Clarithromycin attenuates autophagy in myeloma cells Int J Oncol 37 pp 815-20 PMID: 20811702

23. Moriya $S$ et al (2013) Macrolide antibiotics block autophagy flux and sensitize to bortezomib via endoplasmic reticulum stress-mediated CHOP induction in myeloma cells Int J Oncol 42(5) pp 1541-50 PMID: 23546223 PMCID: 3661227

24. Komatsu $S$ et al (2012) Clarithromycin enhances bortezomib-induced cytotoxicity via endoplasmic reticulum stress-mediated CHOP (GADD153) induction and autophagy in breast cancer cells Int J Oncol 40(4) pp 1029-39

25. Komatsu $S$ et al (2013) Combined treatment with SAHA, bortezomib, and clarithromycin for concomitant targeting of aggresome formation and intracellular proteolytic pathways enhances ER stress-mediated cell death in breast cancer cells Biochem Biophys Res Commun 437(1) pp 41-7 DOI: 10.1016/j.bbrc.2013.06.032 PMID: 23792097

26. Schafranek L et al (2013) Clarithromycin enhances dasatinib-induced cell death in chronic myeloid leukemia cells, by inhibition of late stage autophagy Leuk Lymphoma 54(1) pp 198-201 DOI: 10.3109/10428194.2012.698737

27. Carella AM et al (2012) Clarithromycin potentiates tyrosine kinase inhibitor treatment in patients with resistant chronic myeloid leukemia Leuk Lymphoma 53(7) pp 1409-11 DOI: 10.3109/10428194.2012.656105 PMID: 22233113

28. Durie BGM et al (1997) Clarithromycin (Biaxin) as primary treatment for myeloma Blood 90(279a) pp abstr suppl 1

29. Musto $\mathrm{P}$ et al (2002) Inefficacy of clarithromycin in advanced multiple myeloma: a definitive report Haematologica 87(6) pp 658-59 PMID: 12031924

30. Morris TC, Ranaghan L and Morrison J (2001) Phase II trial of clarithromycin and pamidronate therapy in myeloma Med Oncol (Northwood, London, England) 18(1) pp 79-84 DOI: 10.1385/MO:18:1:79

31. Stewart AK et al (1999) Lack of response to short-term use of clarithromycin (BIAXIN) in multiple myeloma Blood 93(12) pp 4441 PMID: 10391696

32. Moreau $\mathrm{P}$ et al (1999) Lack of efficacy of clarithromycin in advanced multiple myeloma. Intergroupe Français du Myélome (IFM) Leukemia 13(3) pp 490-1 DOI: 10.1038/sj.leu.2401332 PMID: 10086745

33. Vescio RA (2001) American Society of Hematology meeting Blood 98 pp abstract 5007

34. Coleman $M$ et al (2002) BLT-D (clarithromycin [Biaxin], low-dose thalidomide, and dexamethasone) for the treatment of myeloma and Waldenström's macroglobulinemia Leuk Lymphoma 43(9) pp 1777-82 DOI: 10.1080/1042819021000006303

35. Dimopoulos MA et al (2003) Treatment of Waldenstrom's macroglobulinemia with single-agent thalidomide or with the combination of clarithromycin, thalidomide and dexamethasone Semin Oncol 30(2) pp 265-9 DOI: 10.1053/sonc.2003.50079 PMID: 12720150 
36. Coleman M et al (2003) Treatment of Waldenstrom's macroglobulinemia with clarithromycin, low-dose thalidomide, and dexamethasone Semin Oncol 30(2) pp 270-4 DOI: 10.1053/sonc.2003.50044 PMID: 12720151

37. Niesvizky R et al (2003) Dexamethasone alone, or in combination with low-dose thalidomide as induction therapy for advanced multiple myeloma, and the effect of the addition of clarithromycin on response rate. Interim results of a prospective, sequential, randomized Trial Blood 102(11) pp 237a Ember 16

38. Morris et al (2008) Clarithromycin with low dose dexamethasone and thalidomide is effective therapy in relapsed/refractory myeloma Br J Haematol 143(3) pp 349-54 DOI: 10.1111/j.1365-2141.2008.07360.x PMID: 18759764

39. Knight R (2005) IMiDs: a novel class of immunomodulators Semin Oncol 32(4 Suppl 5) pp S24-30 DOI: 10.1053/j. seminoncol.2005.06.018 PMID: 16085014

40. Niesvizky R et al (2008) BiRD (Biaxin [clarithromycin]/Revlimid [lenalidomide]/dexamethasone) combination therapy results in high complete- and overall-response rates in treatment-naive symptomatic multiple myeloma Blood 111(3) pp 1101-9 DOI: 10.1182/blood-2007-05-090258

41. Rossi et al (2013) BiRd (clarithromycin, lenalidomide, dexamethasone): an update on long-term lenalidomide therapy in previously untreated patients with multiple myeloma Blood 121(11) pp 1982-5 DOI: 10.1182/blood-2012-08-448563 PMID: 23299315 PMCID: $\underline{3596960}$

42. Rajkumar SV (2005) Combination therapy with lenalidomide plus dexamethasone (Rev/Dex) for newly diagnosed myeloma Blood 106(13) pp 4050-3 DOI: 10.1182/blood-2005-07-2817 PMID: 16118317 PMCID: 1895238

43. Rajkumar SV et al (2010) Lenalidomide plus high-dose dexamethasone versus lenalidomide plus low-dose dexamethasone as initial therapy for newly diagnosed multiple myeloma: an open-label randomised controlled trial Lancet Oncol 11(1) pp 29-37 DOI: $10.1016 /$ S1470-2045(09)70284-0

44. Gay $\mathrm{F}$ et al (2010) Clarithromycin (Biaxin)-lenalidomide-low-dose dexamethasone (BiRd) versus lenalidomide-low-dose dexamethasone (Rd) for newly diagnosed myeloma Am J Hematol 85(9) pp 664-9 DOI: 10.1002/aih.21777 PMID: 20645430 PMCID: $\underline{3956597}$

45. Kato $\mathrm{H}$ et al (2013) Addition of clarithromycin to lenalidomide/low-dose dexamethasone was effective in a case of relapsed myeloma after long-term use of lenalidomide Ann Hematol 92(12) pp 1711-2 DOI: 10.1007/s00277-013-1761-x PMID: 23625297

46. Ghosh $\mathrm{N}$ et al (2014) Clarithromycin overcomes resistance to lenalidomide and dexamethasone in multiple myeloma $\mathrm{Am}$ J Hematol 89(8) pp E116-20 DOI: 10.1002/ajh.23733 PMID: $\underline{24723438}$

47. Mark TM et al (2014) Thalidomide, clarithromycin, lenalidomide and dexamethasone therapy in newly diagnosed, symptomatic multiple myeloma Leuk Lymphoma 55(12) 2842-9 DOI: 10.3109/10428194.2014.896005 PMID: 24576165

48. Rossi AC et al (2012) Clarithromycin, pomalidomide, and dexamethasone (ClaPD) in relapsed or refractory multiple myeloma J Clinical Oncol 30 pp (suppl; abstr 8036)

49. Mark T et al (2012) ClaPD (Clarithromycin, Pomalidomide, Dexamethasone) therapy in relapsed or refractory multiple myeloma ASH Annual Meeting pp abstract 77

50. Fischbach W (2004) Long term outcome of patients with gastric marginal zone B cell lymphoma of mucosa associated lymphoid tissue (MALT) following exclusive Helicobacter pylori eradication therapy: experience from a large prospective series Gut 53(1) pp 34-7 DOI: 10.1136/gut.53.1.34

51. Ruskone-Fourmestraux A (2001) Predictive factors for regression of gastric MALT lymphoma after anti-Helicobacter pylori treatment Gut 48(3) pp 297-303 DOI: 10.1136/gut.48.3.297 PMID: 11171816 PMCID: 1760135 
52. Cavanna L et al (2008) High grade B-cell gastric lymphoma with complete pathologic remission after eradication of Helicobacter pylori infection: report of a case and review of the literature World J Surg Oncol 6 pp 35 DOI: 10.1186/1477-7819-6-35 PMID: 18353178 PMCID: 2329637

53. Chen LT et al (2001) Prospective study of Helicobacter pylori eradication therapy in stage I(E) high-grade mucosa-associated lymphoid tissue lymphoma of the stomach J Clinic Oncol 19(22) pp 4245-51

54. Chen LT et al (2005) Long-term results of anti-Helicobacter pylori therapy in early-stage gastric high-grade transformed MALT lymphoma J Natl Cancer Inst 97(18) pp 1345-53 DOI: 10.1093/inci/dji277 PMID: 16174856

55. Salam I et al (2001) Regression of primary high-grade gastric B-cell lymphoma following Helicobacter pylori eradication Eur J Gastroenterol Hepatol 13(11) pp 1375-8 DOI: $\underline{10.1097 / 00042737-200111000-00018}$ PMID: 11692066

56. Morgner A et al (2001) Complete remission of primary high-grade B-cell gastric lymphoma after cure of Helicobacter pylori infection J Clin Oncol 19(7) pp 2041-8 PMID: 11283137

57. Alsolaiman MM et al (2003) Five years of complete remission of gastric diffuse large B cell lymphoma after eradication of Helicobacter pylori infection Gut 52(4) pp 507-9 DOI: 10.1136/gut.52.4.507 PMID: 12631659 PMCID: 1773612

58. Sugimoto $M$ et al (2001) Regression of primary gastric diffuse large B-cell lymphoma after eradication of Helicobacter pylori Gastrointest Endosc 54(5) pp 643-5 DOI: 10.1067/mge.2001.118647 PMID: 11677489

59. Kuo SH et al (2012) Helicobacter pylori eradication therapy is effective in the treatment of early-stage $\mathrm{H}$ pylori-positive gastric diffuse large B-cell lymphomas Blood 119(21) pp 4838-44 quiz 5057 DOI: 10.1182/blood-2012-01-404194 PMID: 22403257

60. Ferreri AJ et al (2012) Helicobacter pylori eradication as exclusive treatment for limited-stage gastric diffuse large B-cell lymphoma: results of a multicenter phase 2 trial Blood 120(18) pp 3858-60 DOI: 10.1182/blood-2012-06-438424 PMID: 23118214

61. Sauter C and Blum S (2003) Regression of lung lesions in Hodgkin's disease by antibiotics: case report and hypothesis on the etiology of Hodgkin's disease Am J Clin Oncol 26(1) pp 92-4 DOI: 10.1097/00000421-200302000-00018 PMID: 12576932

62. Inoue $F$ and Chiba T (1999) Regression of MALT lymphoma of the rectum after anti-H pylori therapy in a patient negative for H pylori Gastroenterology 117(2) pp 514-5 DOI: 10.1053/gast.1999.0029900514b PMID: 10465640

63. Arima $\mathrm{N}$ and Tsudo M (2003) Extragastric mucosa-associated lymphoid tissue lymphoma showing the regression by Helicobacter pylori eradication therapy Brit J Haematol 120(5) pp 790-2 DOI: 10.1046/j.1365-2141.2003.04170.x

64. Ochi M et al (2006) Regression of primary low-grade mucosa-associated lymphoid tissue lymphoma of duodenum after longterm treatment with clarithromycin Scand J Gastroenterol 41(3) pp 365-9 DOI: 10.1080/00365520500331224 PMID: 16497629

65. Govi S et al (2010) Six-month oral clarithromycin regimen is safe and active in extranodal marginal zone B-cell lymphomas: final results of a single-centre phase II trial Br J Haematol 150(2) pp 226-9 PMID: 20433679

66. Ishimatsu $Y$ et al (2010) Two cases with pulmonary mucosa-associated lymphoid tissue lymphoma successfully treated with clarithromycin Chest 138(3) pp 730-3 DOI: 10.1378/chest.09-2358 PMID: 20822996

67. Saad AS (2014) An open-label randomized controlled phase II study of clarithromycin (CL) plus CVP in patients (pts) with previously untreated stage III/IV indolent non Hodgkin lymphoma (NHL) J Clin Oncol 32(suppl 3) pp abstr e19510

68. Ohe M and Hashino S (2011) A case of follicular B-cell lymphoma treated using clarithromycin Korean J Hematol 46(3) pp 203-6 DOI: 10.5045/kjh.2011.46.3.203 PMID: 22065978 PMCID: $\underline{3208206}$

69. Ohe M, Hashino $S$ and Hattori A (2012) Successful treatment of diffuse large B-cell lymphoma with clarithromycin and prednisolone Korean J Hematol 47(4) pp 293-7 DOI: 10.5045/kjh.2012.47.4.293

70. Ohe Mi and Hashino S (2013) Successful treatment of recurrent follicular B-cell lymphoma with clarithromycin, prednisolone, and cyclophosphamide Korean J Inter Med 28(3) pp 377-9 DOI: 10.3904/kjim.2013.28.3.377 
71. Mikasa K et al (1997) Significant survival benefit to patients with advanced non-small-cell lung cancer from treatment with clarithromycin Chemotherapy 43(4) pp 288-96 DOI: 10.1159/000239580 PMID: $\underline{9209786}$

72. Sakamoto $\mathrm{M}$ et al (2001) Anti-cachectic effect of clarithromycin for patients with unresectable non-small cell lung cancer Chemotherapy 47(6) pp 444-51 DOI: $10.1159 / 000048556$

73. Hirata T et al (2004) Suppression of postoperative systemic inflammatory response syndrome with clarithromycin following lung cancer surgery Eur Surg Res 36(1) pp 13-9 DOI: $\underline{10.1159 / 000075069}$ PMID: 14730218

74. Chow LW et al (2000) Clarithromycin attenuates mastectomy-induced acute inflammatory response Clinical Diagn Lab Immunol 7(6) pp 925-31

75. Ishimatsu $Y$ et al (2004) Macrolide antibiotics induce apoptosis of human peripheral lymphocytes in vitro Int $J$ Antimicrob Agents 24(3) pp 247-53 DOI: 10.1016/j.ijantimicag.2004.03.022 PMID: $\underline{15325428}$

76. Ichiyama $\mathrm{T}$ et al (2001) Clarithromycin inhibits NF-kappaB activation in human peripheral blood mononuclear cells and pulmonary epithelial cells Antimicrob Agents Chemother 45(1) pp 44-7 DOI: 10.1128/AAC.45.1.44-47.2001

77. Kuo SH et al (2004) Nuclear expression of BCL10 or nuclear factor kappa B predicts Helicobacter pylori-independent status of early-stage, high-grade gastric mucosa-associated lymphoid tissue lymphomas J Clin Oncol 22(17) pp3491-7 DOI: 10.1200/ JCO.2004.10.087 PMID: 15337797

78. Chen $Y$ et al (2010) Diffuse large B-cell lymphoma in Chinese patients: immunophenotypic and cytogenetic analyses of 124 cases Am J Clin Pathol 133(2) pp 305-13 DOI: 10.1309/AJCP4H6ADGYDZMOA PMID: 20093241

79. Ohashi $\mathrm{S}$ et al (2000) A clinicopathologic study of gastric mucosa-associated lymphoid tissue lymphoma Cancer 88(10) pp 2210-9 DOI: 10.1002/(SICI)1097-0142(20000515)88:10\&lt;2210::AID-CNCR3\&gt;3.0.CO;2-I PMID: 10820341

80. Fukui T et al (2004) Immunogenetic analysis of gastric MALT lymphoma-like lesions induced by Helicobacter pylori infection in neonatally thymectomized mice Lab Invest 84(4) pp 485-92 DOI: 10.1038/labinvest.3700056 PMID: 14968120

81. Morgner A et al (2001) Helicobacter-induced expression of Bcl-X(L) in B lymphocytes in the mouse model: a possible step in the development of gastric mucosa-associated lymphoid tissue (MALT) lymphoma Int J Cancer 92(5) pp 634-40 DOI: 10.1002/1097-0215(20010601)92:5\&lt;634::AID-IJC1241\&gt;3.0.CO;2-V PMID: 11340565

82. Mizunoe $S$ et al (2004) Clarithromycin and azithromycin induce apoptosis of activated lymphocytes via down-regulation of Bcl-xL Int Immunopharmacol 4(9) pp 1201-7 DOI: 10.1016/j.intimp.2004.05.011 PMID: 15251115

83. Semino-MC et al (2013) Antibiotic treatment decreases microbial burden associated with pseudomyxoma peritonei and affects $\boldsymbol{\beta}$-catenin distribution Clin Cancer Res 19(14) pp 3966-76 DOI: 10.1158/1078-0432.CCR-13-0616

84. Zhang W and Liu HT (2002) MAPK signal pathways in the regulation of cell proliferation in mammalian cells Cell Res 12(1) pp 9-18 DOI: $\underline{10.1038 / s j . c r .7290105}$ PMID: 11942415

85. Johnson GL and Lapadat R (2002) Mitogen-activated protein kinase pathways mediated by ERK, JNK, and p38 protein kinases Science 298(5600) pp 1911-2 DOI: 10.1126/science.1072682 PMID: 12471242

86. Shinkai $\mathrm{M}$ et al (2006) Clarithromycin delays progression of bronchial epithelial cells from $\mathbf{G} 1$ phase to $\mathbf{S}$ phase and delays cell growth via extracellular signal-regulated protein kinase suppression Antimicrob Agents Chemother 50(5) pp 1738-44 DOI: 10.1128/AAC.50.5.1738-1744.2006 PMID: 16641444 PMCID: 1472217

87. Webb CP et al (1998) Signaling pathways in Ras-mediated tumorigenicity and metastasis Proc Natl Acad Sci U.S.A. 95(15) pp 8773-8 DOI: 10.1073/pnas.95.15.8773 PMID: $\underline{9671754}$ PMCID: $\underline{21152}$

88. Mishima K, Inoue K and Hayashi $Y$ (2002) Overexpression of extracellular-signal regulated kinases on oral squamous cell carcinoma Oral Oncol 38(5) pp 468-74 DOI: 10.1016/S1368-8375(01)00104-X PMID: 12110341 
89. Vicent $\mathrm{S}$ et al (2004) ERK1/2 is activated in non-small-cell lung cancer and associated with advanced tumours $\mathrm{Br} J$ Cancer 90 (5) pp 1047-52 DOI: 10.1038/sj.bjc.6601644 PMID: 14997206 PMCID: 2409626

90. Burger R (2013) Impact of interleukin-6 in hematological malignancies Transfus Med Hemother 40(5) pp 336-43 DOI: 10.1159/000354194 PMID: 24273487 PMCID: $\underline{3822278}$

91. Niesvizky R et al (2006) Clarithromycin, lenalidomide and dexamethasone combination therapy as primary treatment of multiple myeloma $J$ Clin Oncol 24(18) pp 7545

92. Niesvizky R et al (2007) Prophylactic low-dose aspirin is effective antithrombotic therapy for combination treatments of thalidomide or lenalidomide in myeloma Leuk Lymphoma 48(12) pp 2330-7 DOI: 10.1080/10428190701647887 PMID: 18067007

93. Mark T et al (2008) Atypical serum immunofixation patterns frequently emerge in immunomodulatory therapy and are associated with a high degree of response in multiple myeloma Br J Haematol 143(5) pp 654-60 DOI: 10.1111/j.1365-2141.2008.07374.x PMID: 18950461 PMCID: 3626496

94. Niesvizky R et al (2002) Clarithromycin potentiates the response to dexamethasone in chemotherapy naïve multiple myeloma patients: a prospective, sequential, randomized trial Blood 100(11) pp abstract 5119

95. Fost DA et al (1999) Inhibition of methylprednisolone elimination in the presence of clarithromycin therapy J Allergy Clin Immunology 103(6) pp 1031-5 DOI: 10.1016/S0091-6749(99)70175-2

96. Spahn JD et al (2001) Clarithromycin potentiates glucocorticoid responsiveness in patients with asthma: results of a pilot study Ann Allergy Asthma Immunol 87(6) pp 501-5 DOI: 10.1016/S1081-1206(10)62264-8

97. Abe $\mathrm{S}$ et al (2000) Interleukin-8 gene repression by clarithromycin is mediated by the activator protein-1 binding site in human bronchial epithelial cells Am J Respir Cell Mol Biol 22(1) pp 51-60 DOI: $\underline{10.1165 / a j r c m b .22 .1 .3400}$

98. Schmidt $S$ et al (2004) Glucocorticoid-induced apoptosis and glucocorticoid resistance: molecular mechanisms and clinical relevance Cell Death Differ 11 (Suppl 1) pp S45-55 DOI: 10.1038/sj.cdd.4401456 PMID: 15243581

99. Laane $\mathrm{E}$ et al (2009) Cell death induced by dexamethasone in lymphoid leukemia is mediated through initiation of autophagy Cell Death Differ 16(7) pp 1018-29 DOI: 10.1038/cdd.2009.46 PMID: 19390558

100. Yang ZJ et al (2011) The role of autophagy in cancer: therapeutic implications Mol Cancer Ther 10(9) pp 1533-41 DOI: 10.1158/1535-7163.MCT-11-0047 PMID: 21878654 PMCID: $\underline{3170456}$

101.Fung $C$ et al 2008) Induction of autophagy during extracellular matrix detachment promotes cell survival Mol Biol Cell 19(3) pp 797-806 DOI: 10.1091/mbc.E07-10-1092 PMCID: 2262959

102. Puleston DJ and Simon AK (2014) Autophagy in the immune system Immunology 141(1) pp 1-8 DOI: 10.1111/imm.12165 PMCID: $\underline{3893844}$

103. Baginska J et al (2013) Granzyme B degradation by autophagy decreases tumor cell susceptibility to natural killer-mediated lysis under hypoxia Proc Natl Acad Sci U.S.A 110(43) pp 17450-5 DOI: 10.1073/pnas.1304790110 PMID: 24101526 PMCID: $\underline{3808626}$

104.Kikuchi T (2002) Clarithromycin suppresses lipopolysaccharide-induced interleukin-8 production by human monocytes through AP-1 and NF-kappaB transcription factors J Antimicrob Chemother 49(5) pp 745-55 DOI: 10.1093/jac/dkf008 PMID: 12003967

105. Shinkai M et al (2006) Macrolide antibiotics modulate ERK phosphorylation and IL-8 and GM-CSF production by human bronchial epithelial cells Am J Physiol Lung Cell Mol Physiol 290(1) pp L75-85 DOI: 10.1152/aiplung.00093.2005

106. Morikawa K et al (1996) Modulatory effect of antibiotics on cytokine production by human monocytes in vitro Antimicrob Agents Chemother 40(6) pp 1366-70 PMID: 8726002 PMCID: 163332 
107. Takizawa $\mathrm{H}$ et al (1995) Erythromycin suppresses interleukin 6 expression by human bronchial epithelial cells: a potential mechanism of its anti-inflammatory action Biochem Biophysi Res Commun 210(3) pp 781-6 DOI: 10.1006/bbrc.1995.1727

108. Kohyama $T$ et al (1999) Fourteen-member macrolides inhibit interleukin-8 release by human eosinophils from atopic donors Antimicrob Agents Chemother 43(4) pp 907-11 PMID: 10103198 PMCID: 89224

109. Basyigit I et al (2004) The effect of clarithromycin on inflammatory markers in chronic obstructive pulmonary disease: preliminary data Ann Pharmacother 38(9) pp 1400-5 DOI: 10.1345/aph.1D634 PMID: 15252191

110. Pukhalsky AL et al (2004) Anti-inflammatory and immunomodulating effects of clarithromycin in patients with cystic fibrosis lung disease Mediators Inflamm 13(2) pp 111-7 DOI: 10.1080/09629350410001688495 PMID: 15203552 PMCID: 1781547

111. Crabtree JE et al (1993) Gastric interleukin-8 and IgA IL-8 autoantibodies in Helicobacter pylori infection Scand J Immuno/ 37(1) pp 65-70 DOI: 10.1111/j.1365-3083.1993.tb01666.x PMID: $\underline{8418474}$

112 Peek RM Jr (2001) IV. Helicobacter pylori strain-specific activation of signal transduction cascades related to gastric inflammation Am J Physiol Gastrointest Liver Physiol 280(4) pp G525-30 PMID: 11254477

113. Shimada T and Terano A (1998) Chemokine expression in Helicobacter pylori-infected gastric mucosa $J$ Gastroenterol 33(5) pp 613-7 DOI: $\underline{10.1007 / s 005350050146}$ PMID: $\underline{9773923}$

114. Aihara $\mathrm{M}$ et al (1997) Mechanisms involved in Helicobacter pylori-induced interleukin-8 production by a gastric cancer cell line, MKN45 Infect Immun 65(8) pp 3218-24 PMID: $\underline{9234778}$ PMCID: 175455

115. Yasumoto $\mathrm{K}$ et al (1992) Tumor necrosis factor alpha and interferon gamma synergistically induce interleukin 8 production in a human gastric cancer cell line through acting concurrently on AP-1 and NF-kB-like binding sites of the interleukin 8 gene J Biol Chem 267(31) pp 22506-11 PMID: 1331059

116. Adachi T et al (1996) Eosinophil apoptosis caused by theophylline, glucocorticoids, and macrolides after stimulation with IL-5 J Allergy Clin Immunol 98(6 Pt 2) pp S207-15 DOI: 10.1016/S0091-6749(96)70068-4 PMID: 8977529

117. Li Y et al (2002) Fourteen-membered ring macrolides inhibit vascular cell adhesion molecule 1 messenger RNA induction and leukocyte migration: role in preventing lung injury and fibrosis in bleomycin-challenged mice Chest 122(6) pp 2137-45 DOI: 10.1378/chest.122.6.2137 PMID: $\underline{12475858}$

118. Morikawa K (1994) Immunomodulatory effects of three macrolides, midecamycin acetate, josamycin, and clarithromycin, on human T-lymphocyte function in vitro Antimicrob Agents Chemother 38(11) pp 2643-7 DOI: 10.1128/AAC.38.11.2643 PMID: 7532933 PMCID: $\underline{188255}$

119. Morikawa K (2002) Modulatory effect of macrolide antibiotics on the Th1- and Th2-type cytokine production Int $J$ Antimicrob Agents 19(1) pp 53-9 DOI: 10.1016/S0924-8579(01)00457-5 PMID: 11814768

120.Williams AC (2005) Differential effects of three antibiotics on T helper cell cytokine expression J Antimicrob Chemother 56(3) pp 502-6 DOI: $\underline{10.1093 / j a c / d k i 251}$ PMID: $\underline{16006447}$

121. Sugiyama $\mathrm{K}$ et al (2007) Differing effects of clarithromycin and azithromycin on cytokine production by murine dendritic cells Clin Exp Immunol 147(3) pp 540-6 DOI: 10.1111/j.1365-2249.2007.03299.x PMID: 17302905 PMCID: 1810497

122. Gimbrone MA Jr et al (1974) Tumor growth and neovascularization: an experimental model using the rabbit cornea $J$ Natl Cancer Inst 52(2) pp 413-27 PMID: $\underline{4816003}$

123. Ma XH et al (2014) Targeting ER stress-induced autophagy overcomes BRAF inhibitor resistance in melanoma $J$ Clin Invest 124(3) pp 1406-17 DOI: $\underline{10.1172 / J C I 70454}$ PMID: 24569374 PMCID: $\underline{3934165}$

124.Levy JM et al (2014) Autophagy Inhibition Improves Chemosensitivity in BRAFV600E Brain Tumors Cancer Discov 4(7) pp 773-80 DOI: $\underline{10.1158 / 2159-8290 . C D-14-0049}$ PMID: 24823863 PMCID: $\underline{4090283}$ 
125.Matsumoto T, lida M and Shimizu M (1997) Regression of mucosa-associated lymphoid-tissue lymphoma of rectum after eradication of Helicobacter pylori Lancet 350(9071) pp 115-6 DOI: 10.1016/S0140-6736(05)61818-1 PMID: 9228971

126. Steinbach $\mathrm{G}$ et al (1999) Antibiotic treatment of gastric lymphoma of mucosa-associated lymphoid tissue. An uncontrolled trial Ann Intern Med 131(2) pp 88-95 DOI: 10.7326/0003-4819-131-2-199907200-00003 PMID: 10419446

127.Papa A et al (2000) Helicobacter pylori eradication and remission of low-grade gastric mucosa-associated lymphoid tissue lymphoma: a long-term follow-up study J Clin Gastroenterol 31(2) pp 169-71 DOI: 10.1097/00004836-200009000-00018 PMID: 10993438

128. Thiede $\mathrm{C}$ et al (2001) Long-term persistence of monoclonal B cells after cure of Helicobacter pylori infection and complete histologic remission in gastric mucosa-associated lymphoid tissue B-cell lymphoma J Clin Oncol 19(6) pp 1600-9 PMID: 11250988

129. Matsumoto T and lida M (2005) [Extra-gastric lymphoma of MALT type and H pylori eradication] Nihon Rinsho Japanese J Clin Med 63 (Suppl 1) pp 308-11

\section{Repurposing Drugs in Oncology (ReDO)—clarithromycin as an anti-cancer agent-supplementary material}

\section{Introduction}

The following drugs warrant further investigation in combination with clarithromycin (CAM), both in pre-clinical studies and potentially in clinical trials. These combinations, listed in Table 1, have been selected on the basis of existing pre-clinical and clinical experience in each of the indications. Haematologic malignancies are not listed as the research agenda with clarithromycin is more advanced in these diseases. All of these proposed combinations are expected to display relatively low toxicity and yield low cost and are generally available agents.

\section{Higher priority agents}

The agents listed below have a high degree of clinical evidence of efficacy and are currently either in clinical use in oncology or are currently being investigated in clinical trials. They have been selected as potential agents to be used in combination with CAM and existing standard of care treatments. Note that these drugs are not listed in order of priority.

Table 1. Proposed drug combinations with CAM and standard of care in different cancers.

\begin{tabular}{|l|l|l|}
\hline Disease & Targets & Drug combination (with selected references) \\
\hline Breast cancer & $\begin{array}{l}\text { Pro-inflammatory cytokines, monocytes ... } \\
\text { During and after surgery }\end{array}$ & NSAIDs [18], aspirin [19], beta-blockers [20] \\
\hline NSCLC & $\begin{array}{l}\text { Pro-inflammatory cytokines, monocytes ... } \\
\text { During and after surgery and/or radiotherapy }\end{array}$ & $\begin{array}{l}\text { NSAIDs [13, 14], aspirin [21], cimetidine [22], } \\
\text { beta-blockers [14] }\end{array}$ \\
\hline NSCLC & Angiogenesis and endothelial cells & $\begin{array}{l}\text { Metronomic [6, 23] or maintenance [1, 2] } \\
\text { chemotherapy, aspirin [19, 24] }\end{array}$ \\
\hline $\begin{array}{l}\text { All solid tumours, } \\
\text { highly inflammatory } \\
\text { (e.g. high neutrophils } \\
\text { to lymphocytes Ratio) }\end{array}$ & $\begin{array}{l}\text { Pro-inflammatory cytokines, monocytes, } \\
\text { dendritic cells, T-cell trafficking ... }\end{array}$ & NSAIDs [13], metronomic chemotherapy [23] \\
\hline $\begin{array}{l}\text { Melanoma and other } \\
\text { immunogenic tumours }\end{array}$ & $\begin{array}{l}\text { Immune cells of the tumour environment } \\
\text { (effector T-cells, Myeloid-derived suppressor } \\
\text { cells, regulator T-cells, macrophages) }\end{array}$ & $\begin{array}{l}\text { Immune checkpoint inhibitors [25], cellular } \\
\text { immunotherapies [26] }\end{array}$ \\
\hline
\end{tabular}


- Maintenance chemotherapy: combining CAM with a maintenance regimen could be of interest especially in lung cancer. Pemetrexed maintenance is now standard of care in non-squamous, non-small cell lung cancer (NSCLC) [1, 2], and adding CAM to an already effective maintenance regimen could turn out to be beneficial as like in Mikasa's trial where he used CAM as a maintenance regimen as well [3]. Lung cancer frequently develops in patients with COPD which is characterised by a risk of infectious exacerbation and systemic inflammation. The antibiotic and anti-inflammatory properties of macrolides are certainly attractive in this patient population [4] knowing that a trial of prophylactic antibiotics—with a macrolide (roxithromycin) and a fluoroquinolone —in SCLC patients have demonstrated a clear benefit of this strategy [5]. It would be worth testing this hypothesis for other cancers characterised by a strong chronic inflammatory response.

- Metronomic chemotherapy: in heavily pre-treated patients, a combination of CAM with metronomic chemotherapy could be particularly attractive in advanced or metastatic lung cancer after failure of one or several lines of chemotherapy. A trial in patients with advanced NSCLC has shown that metronomic vinorelbine as a single agent was able to induce responses and stabilisation in heavily pre-treated patients [6] and Mikasa's trial actually used CAM in a typical metronomic schedule [3]. Both interventions have an effect on the tumour microenvironment which could be an advantage in heavily pre-treated patients with refractory tumours. Tolerability of both CAM (reviewed in this article) and metronomic chemotherapy [7] has been generally good and the combination of the two is not expected to cause significant problems as long as CAM and chemotherapy drug(s) are not competing with CYP3A4 for their respective metabolism.

- Non-steroidal anti-inflammatory drugs (NSAIDs) such as diclofenac: in most cancers, the systemic inflammation response becomes predominant at some point and is associated with a poor prognosis [8]. Efforts are being made to target specific components of this systemic response. In addition to celecoxib which has been used in many cancer experiments and trials [9], other anti-inflammatory drugs have the potential to dramatically modify the inflammatory response leading amongst other things to modification of the sub-types of immune cells populating the environment of tumours [10]. A marker study validating this concept in a few patients might be an important prelude to justifying such a trial with survival endpoints.

- Drugs in the perioperative period: in addition to the use of CAM and anti-inflammatory drugs in patients with advanced disease, data indicate that both CAM [11, 12] and anti-inflammatory drugs [13] are able to affect the inflammatory and pro-angiogenic response induced by cancer surgery. A perioperative intervention combining these two might prove even more effective as has been shown experimentally by combining NSAID and beta blockers [14].

- Immune checkpoint inhibitors: even though this would be an expensive strategy because of the cost associated with the use of anti- cytotoxic T-lymphocyte-associated protein 4 (CTLA4) and anti-programme cell death ligant-1 (PD-(L)1) antibodies, it would make sense, thanks to the prolonged effect of CAM on numerous pro-inflammatory cytokines [15]. Non-responders to immune checkpoint blockade or those showing minimal response may show improved response. The effect of adding CAM to anti-PD-(L)1 antibodies could be tested in mouse models in concomitant or sequential combination with anti-PD-(L)1 antibodies.

- BRAF-inhibitors: In patients with BRAF-mutated tumours, CAM could be proposed together with BRAF inhibitors to delay resistance as recent work have shown that resistance to BRAF inhibitors could be overcome by targeting autophagy in BRAF (V600E) melanoma [16], as well as in other BRAF (V600E) mutated tumours [17]. CAM seems an interesting alternative to chloroquine in targeting autophagy.

\section{References}

1. Ciuleanu T et al (2009) Maintenance pemetrexed plus best supportive care versus placebo plus best supportive care for non-small-cell lung cancer: a randomised, double-blind, phase 3 study Lancet 374(9699) pp 1432-40 DOI: 10.1016/S01406736(09)61497-5 PMID: 19767093

2. Paz-Ares LG et al (2013) PARAMOUNT: Final overall survival results of the phase III study of maintenance pemetrexed versus placebo immediately after induction treatment with pemetrexed plus cisplatin for advanced nonsquamous non-small-cell lung cancer J Clin Oncol 31(23) pp 2895-902 DOI: 10.1200/JCO.2012.47.1102 PMID: 23835707

3. Mikasa K et al (1997) Significant survival benefit to patients with advanced non-small-cell lung cancer from treatment with clarithromycin Chemotherapy 43(4) pp 288-96 DOI: 10.1159/000239580 PMID: $\underline{9209786}$ 
4. Alifano $\mathrm{M}$ et al (2014) Systemic Inflammation, Nutritional Status and Tumor Immune Microenvironment Determine Outcome of Resected Non-Small Cell Lung Cancer PloS One 9(9) p e106914 DOI: 10.1371/journal.pone.0106914 PMID: 25238252 PMCID: 4169516

5. Tjan-Heijnen VC et al (2001) Reduction of chemotherapy-induced febrile leucopenia by prophylactic use of ciprofloxacin and roxithromycin in small-cell lung cancer patients: an EORTC double-blind placebo-controlled phase III study Ann Ooncol 12(10) pp 1359-68 DOI: 10.1023/A:1012545507920

6. Kontopodis E et al (2013) A phase II study of metronomic oral vinorelbine administered in the second line and beyond in non-small cell lung cancer (NSCLC): a phase II study of the Hellenic Oncology Research Group J Chemothe (Florence, Italy) 25(1) pp 49-55 DOI: 10.1179/1973947812Y.0000000050

7. André $\mathrm{N}$ et al (2014) Metronomics: towards personalized chemotherapy? Nat Rev Clin Oncol 11(7) pp 413-31 DOI: $10.1038 /$ nrclinonc.2014.89 PMID: 24913374

8. Templeton AJ et al (2014) Prognostic Role of Neutrophil-to-Lymphocyte Ratio in Solid Tumors: A Systematic Review and MetaAnalysis J Natl Cancer Inst 106(6) pp 1-11 DOI: 10.1093/inci/dju124

9. Jendrossek V (2013) Targeting apoptosis pathways by Celecoxib in cancer Cancer Lett 332(2) pp 313-24 DOI: 10.1016/j. canlet.2011.01.012

10. Hussain $\mathrm{M}$ et al (2012) Non-steroidal anti-inflammatory drugs, tumour immunity and immunotherapy Pharmacol Res 66(1) pp 7-18 DOI: 10.1016/j.phrs.2012.02.003 PMID: 22449788

11.Chow LW et al (2000) Clarithromycin attenuates mastectomy-induced acute inflammatory response Clin Diagn Lab Immunol 7(6) pp 925-31 PMID: 11063500 PMCID: $\underline{95987}$

12. Hirata T et al (2004) Suppression of postoperative systemic inflammatory response syndrome with clarithromycin following lung cancer surgery Eur Surg Res 36(1) pp 13-9 DOI: 10.1159/000075069 PMID: 14730218

13. Forget $P$ et al (2013) Neutrophil:lymphocyte ratio and intraoperative use of ketorolac or diclofenac are prognostic factors in different cohorts of patients undergoing breast, lung, and kidney cancer surgery Ann Surg Oncol 20(Suppl 3) pp S650-60 DOI: 10.1245/s10434-013-3136-x PMID: 23884751

14. Benish $\mathrm{M}$ et al (2008) Perioperative use of beta-blockers and COX-2 inhibitors may improve immune competence and reduce the risk of tumor metastasis Ann Surg Oncol 15(1534-4681 (Electronic) pp 2042-52 DOI: 10.1245/s10434-008-9890-5 PMID: 18398660 PMCID: $\underline{3872002}$

15. Kanoh Soichiro and Rubin BK (2010) Mechanisms of action and clinical application of macrolides as immunomodulatory medications Clin Microbiol Rev 23(3) pp 590-615 DOI: 10.1128/CMR.00078-09 PMID: 20610825 PMCID: 2901655

16. Ma XH et al (2014) Targeting ER stress-induced autophagy overcomes BRAF inhibitor resistance in melanoma $J$ Clin Invest 124(3) pp 1406-17 DOI: 10.1172/JCI70454 PMID: 24569374 PMCID: 3934165

17. Levy JM et al (2014) Autophagy Inhibition Improves Chemosensitivity in BRAFV600E Brain Tumors Cancer Discov 4(7) pp 773-80 DOI: 10.1158/2159-8290.CD-14-0049 PMID: 24823863 PMCID: 4090283

18. Forget $\mathrm{P}$ et al (2010) Do intraoperative analgesics influence breast cancer recurrence after mastectomy? A retrospective analysis Anesth Analg 110(6) pp 1630-5

19. Rothwell PM et al (2012) Effect of daily aspirin on risk of cancer metastasis: a study of incident cancers during randomised controlled trials Lancet 379(9826)1591-601 DOI: 10.1016/S0140-6736(12)60209-8 PMID: 22440947

20. Melhem-Bertrandt $A$ et al (2011) Beta-blocker use is associated with improved relapse-free survival in patients with triplenegative breast cancer J Clin Oncol 29(19) pp 2645-52 DOI: 10.1200/JCO.2010.33.4441 PMID: 21632501 PMCID: 3139371 
21. Fontaine $E$ et al (2010) Aspirin and non-small cell lung cancer resections: effect on long-term survival Eur J Cardiothorac Surg 38(1) pp 21-6 DOI: 10.1016/j.ejcts.2010.01.015

22. Zheng $\mathrm{Y}$ et al (2013) Cimetidine suppresses lung tumor growth in mice through proapoptosis of myeloid-derived suppressor cells Mol Immunol 54(1) pp 74-83 DOI: 10.1016/j.molimm.2012.10.035

23. Bertolini F et al (2003) Maximum tolerable dose and low-dose metronomic chemotherapy have opposite effects on the mobilization and viability of circulating endothelial progenitor cells Cancer Res 63(15) pp 4342-6 PMID: 12907602

24. Bambace NM and Holmes CE (2011) The platelet contribution to cancer progression J Thromb Haemost JTH 9(2) pp 237-49 DOI: 10.1111/j.1538-7836.2010.04131.x

25. Topalian S L et al (2014) Survival, durable tumor remission, and long-term safety in patients with advanced melanoma receiving nivolumab J Clinic Oncol 32(10) pp 1020-30 DOI: 10.1200/JCO.2013.53.0105

26. Rosenberg SA et al (2011) Durable complete responses in heavily pretreated patients with metastatic melanoma using T-cell transfer immunotherapy Clin Cancer Res 17(13) pp 4550-7 DOI: 10.1158/1078-0432.CCR-11-0116 PMID: 21498393 PMCID: $\underline{3131487}$ 